\title{
LAS PENAS ALTERNATIVAS A LA CÁRCEL EN CHILE. UN ANÁLISIS DESDE SU EVOLUCIÓN HISTÓRICA*
}

["Alternatives to prison in Chile. An analysis of his historical evolution]

\author{
Sebastián Salinero Echeverría** \\ Universidad de Talca \\ Ana María Morales Peillard*** \\ Fundación Paz Ciudadana \\ Universidad Alberto Hurtado
}

\begin{abstract}
Resumen
Las penas alternativas a la cárcel en Chile cuentan con más de un siglo de historia desde su concepción original como fórmulas de suspensión, pasando por su regulación como medidas alternativas, hasta su construcción actual como penas sustitutivas. El artículo efectúa un análisis bibliográfico de su desarrollo histórico y su consistencia con las reformas experimentadas por las penas alternativas en el derecho comparado, finalizando con una reflexión acerca de las virtudes, defectos y desafíos a futuro que enfrenta su regulación.
\end{abstract}

\section{Palabras clave}

Derecho penal - penas alternativas en Chile - Penas sustitutivas - Ley $\mathrm{N}^{\circ}$ 20.603 .
Abstract

Alternative penalties to prison in Chile have more than a century of history, from its original conception as suspension formulas, passing through its regulation as alternative measures, until its current construction as substitute penalties. The article makes a bibliographical analysis of its historical development and its consistency with the reforms experienced by alternatives in Comparative Law, ending with a reflection about the virtues, defects and future challenges facing the regulation of alternative penalties.

\section{KeYwords}

Criminal Law - alternative penalties in Chile - Substitute penalties - Law $\mathrm{N}^{\circ} 20.603$.

Recibido el 1 de mayo de 2018 y Aprobado el 1 de Julio de 2019.

* El texto es parte del proyecto Fondecyt No 1160970, cuyo investigador responsable es el Dr. Sebastián Salinero Echeverría, y cuyos co-investigadores son la Dra CAna María Morales Peillard y el Dr. Jorge Fábrega Lacoa, titulado "Evaluación de la penas sustitutivas y el camino hacia una política criminal moderna de alternativas a la cárcel".

** Abogado, Magíster en Derecho Penal de la Universidad de Talca. Doctor en Derecho de la Universidad de Lérida, España. Profesor de Derecho Penal y Criminología de la Facultad de Derecho de la Universidad de Talca. ssalinero@utalca.cl.

*** Abogada, Magíster en Política Criminal, London School of Economics and Political Science. Doctora (C) en Criminología de la Universidad de Leicester, Inglaterra. Directora del área Justicia y Reinserción de la Fundación Paz Ciudadana. Profesora de Criminología y Política Criminal de la Facultad de Derecho de la Universidad Alberto Hurtado. amorales@pazciudadana.cl. 


\section{INTRODUCCIÓN}

La pena privativa de libertad ha gobernado como la principal forma de reacción penal de los países de occidente a partir del siglo XVIII. Sin embargo, tal como ocurrió con las penas corporales y principalmente la pena de muerte, ha sido objeto de profundas revisiones en los sistemas legales comparados. Así, se han erigido las "penas alternativas", entendidas genéricamente como cualquier sanción que no implique la privación de libertad $^{1}$, como un sistema de penas más humano, que desde fines del decimonónico han hecho repensar la situación, principalmente por la influencia del conocido programa de Marburgo de 1882, de Von Liszt².

Las reformas experimentadas por los sistemas comparados también tocó las puertas de nuestro país en lo que a sanciones alternativas a la privación de libertad se refiere, por ello se hace necesario saber y conocer el proceso histórico que se desarrolló hasta la actual Ley $\mathrm{N}^{\circ} 20.603$, sobre penas sustitutivas, rescatando cuales fueron los antecedentes que permearon las leyes fundacionales en esta materia y como se decantaron los siguientes procesos legislativos, determinando la ratio legis que los inspiró.

\section{Primeras apariciones de las alternativas a la CÁRCEL EN LA} CODIFICACIÓN CHILENA

Los primeros atisbos de las penas alternativas se encuentran en el Código de Procedimiento Penal de 1906, Ley de enjuiciamiento del antiguo sistema inquisitivo. Ahí, el art. 603 -actual 564- contemplaba la facultad del juez para suspender la ejecución de la pena hasta por tres años, tratándose solamente de faltas y en el caso que estuviésemos frente a un sujeto sin reproche penal pretérito. En palabras de Novoa, esta disposición suponía el reconocimiento de la conocida condena condicional, pero limitada a las faltas $^{3}$, aun cuando, como precisaba Fontecilla, la expresión era incorrecta porque lo que se suspendía no era la condena sino la ejecución de la pena ${ }^{4}$.

1 Salinero, Sebastián - Morales, Ana María - Castro, Álvaro, Análisis comparado y crítico de las alternativas a las penas privativas de libertad. La experiencia española, inglesa y alemana, en Política Criminal 12 (2017), 24, pp. 786-864 y 788.

${ }^{2}$ Von LiszT, Franz, Strafrechtliche vorträge und Aufsätze (Berlin, De Gruyter, 1970), I, p. 513

3 Novon, Eduardo, Curso de Derecho Penal Chileno. Parte General (3a edición, Santiago, Editorial Jurídica de Chile, 2010), II, p. 325.

${ }^{4}$ Fontecilla, Rafael, La pena (Evolución natural, jurídica y técnica). Los problemas modernos y su influencia en el nuevo derecho penal chileno (Santiago, Imp. Cisneros, 1930), p. 353; En palabras de Cury, hubo algunos intentos de introducir la suspensión condicional de la condena, pero prevaleció finalmente el de la pena. CURY, Enrique,
Por ello consideraba más acertada la expresión "Remisión condicional de la pena”, concepto que como se verá no está exento de problemas.

Las razones de su incorporación venían dadas por la experiencia comparada, según dan cuenta las actas de la discusión legislativa, particularmente respecto de las realidades europeas de Inglaterra, Francia y Bélgica y el éxito que suponía la condena condicional tratándose de aquellas personas que delinquen por primera vez. Éxito basado en una reducción importante del número de detenidos en cárceles y la economía que ello significaba para las arcas fiscales. A lo anterior se sumaban problemas prácticos como que la prisión de corto tiempo impedía la regeneración y enmienda del penado, como asimismo podía ser dañosa para los sentimientos de honor y dignidad personales ${ }^{5}$.

La literatura de la época ya daba cuenta de la ineficacia de las penas cortas privativas de libertad y que, muy por el contrario, constituían estímulos poderosos para la reincidencia. Tanto los correccionalistas como los que no compartían dicha denominación, desde la segunda mitad del siglo XIX, reaccionaron contra esta modalidad de pena, indicado que ellas " $n i$ intimidan, ni corrigen, ni inocuizan y, en cambio, hacen perder el temor a la cárcel y ponen al condenado en contacto con gentes perversas y peligrosas, fomentando así, la corrupción del delincuente primario”. De esta manera, reflejaban dos claros inconvenientes: la falta de eficacia correctiva, como los verdaderos cursos de delincuencia que ellos siguen ${ }^{6}$.

\section{LA GENÉSIS DE LA REMISIÓN CONDICIONAL DE LA PENA (LEY No 7.821} DE 1944)

En el año 1944, al alero de un proyecto elaborado en el seno del Instituto de Ciencias Penales (en adelante ICP) se introduce por vez primera la remisión condicional de la pena en el ordenamiento jurídico chileno, mediante Ley No 7.821, de 29 de agosto7. El concepto de "remisión"

Derecho Penal. Parte General (8a edición, Santiago, Ediciones Universidad Católica de Chile, 2005), p. 729.

5 Véase Sesión No 23 de la Comisión Mixta de Senadores y Diputado que tuvo a cargo la revisión del Proyecto de Código de Procedimiento Penal (Valparaíso, Biblioteca del Congreso Nacional); También hay referencia en NovoA, Eduardo, cit. (n. 3), p. 326.

${ }^{6}$ Rojo, Alfredo, La remisión condicional de la ejecución de la pena y las penas cortas de prisión (Santiago, Imp Lers, 1933), p. 29.

7 Sin perjuicio del proyecto del ICP que luego se materializa en ley de la República, la doctrina nacional ya venía reclamando su inclusión Véase: FonTECILLA, cit. (n. 4); Rojo, cit. (n. 6). 
parece haber sido tomado de la regulación española ${ }^{8}$ de la "sentencia condicional" que en 1908 que estableció la "remisión” de la sentencia después de un período de suspensión? . Dicho concepto -utilizado hasta el día de hoy-, constituye un sinónimo de la palabra "perdón"10, aun cuando a través de sus consecuencias no se concede perdón alguno al condenado, sino que supone en cuanto a su naturaleza jurídica, la suspensión de la pena de prisión ${ }^{11}$ condicionada al cumplimiento de un periodo de observación y como se verá al cumplimiento de determinadas condiciones.

La remisión condicional de la pena -que básicamente estaba predispuesta para delincuentes primarios, para diferenciarlos de los habituales o profesionales-, expresaba claras diferencias con la condena condicional ${ }^{12}$ del antiguo art. 603 del Código de Procedimiento Penal tanto en cuanto a su extensión, como respecto los requisitos de procedencia.

Conforme la regulación, debía tratarse de una sentencia que impusiere una pena privativa o restrictiva de libertad que no debía ser superior a un año. Con ello, se reconocía que las penas de corta duración, eran las penas de prisión que no excedían de ese margen de tiempo ${ }^{13}$. Se siguió aquí el criterio más generalizado de los criminólogos de la época de corte positivista que apuntaban a la antigua idea de que el ámbito de las alternativas son las penas cortas de prisión ${ }^{14}$, dado que en períodos cortos no era posible otorgar tratamientos intramuros tendientes a la rehabilitación del condenado. Si bien estos postulados, hoy día resultan altamente debatibles, en la medida que los estudios muestran que no es la extensión de la pena la que puede correlacionarse con la reincidencia sino más bien la existencia de un involucramiento temprano y continuo en actividades antisociales ${ }^{15}$,

\footnotetext{
8 PeÑA, Silvia, La condena condicional en Chile (Valparaíso, Edeval, 1974), p. 11.
}

${ }^{9}$ Barbero, Ruperto, ¿Condena condicional o suspensión de la ejecución de la pena? en Anuario de derecho penal y ciencias penales 23 (1970), 1, pp. 5-34 y 7.

${ }^{10}$ De acuerdo al Diccionario de la lengua española de la Real Academia Española, disponible [en línea]: www.rae.es.

${ }^{11}$ Novoa, cit. (n. 3), p. 322 ss.; Etcheberry, Alfredo, Derecho Penal. Parte General (3a edición, Santiago, Editorial Jurídica de Chile, 1997), II, pp, 210-211.

${ }^{12}$ Lo anterior, aun cuando algunos autores, sin más, equiparaban la remisión condicional de la pena con la condena condicional. PeÑA, cit. (n. 8), p. 11.

${ }^{13}$ Para Novoa la explicación del término de un año obedecía también a que la remisión condicional estaba vinculada con la libertad condicional, la que entra a operar respecto de penas privativas de libertad que exceden de un año. NovOA, cit. (n. 3), p. 327.

${ }^{14}$ Cid, José - Larrauri, Elena, Penas alternativas a la prisión (Barcelona, Bosch, 1997), p. 23.

${ }^{15}$ Andrews, Donald - Bonta, James - Wormith, Stephen, The Recent Past and Near Future of Risk andlor Need Assessment, en Crime Delinquency 52 (2006), 7, pp. 7-27 y 11; Morales, Ana María - MuÑoz, Nicolás - Welsch, Gherman - FÁbreGA, y por ende más relacionado con el requisito relativo a la primariedad delictiva versus condenas previas; el movimiento correccionalista positivista de la época, abogó por la utilización de las alternativas a los condenados acreedores de penas cortas, para quienes sería especialmente eficaz como medio de reducción de la reincidencia delictual ${ }^{16}$.

Algunos autores argumentan que el criterio adoptado por la legislación para entender cuándo estamos frente a una pena de corta duración fue tomada del derecho comparado, considerando países como España, Finlandia, Grecia, Holanda, Italia y Suiza que permitían la suspensión de las penas privativas de libertad no superiores a un año y excepcionalmente hasta dos años de privación tratándose de Dinamarca, Francia, Noruega, Argentina, Brasil, Uruguay, entre otros ${ }^{17}$. A pesar de ello, ya en esa época legislaciones como la francesa permitían la aplicación de la suspensión condicional de la pena cuando la pena impuesta era de 11 días a cinco años; mientras que en el Derecho Norteamericano, la suspensión y la probation operaba para cualquier delito, salvo que estuviere exceptuado expresamente por la ley. Asimismo, en el derecho Alemán, si bien la suspensión sólo procedía cuando la pena no excedía de nueve meses, el juez podía fijar la pena con amplia libertad, debiendo considerar para ello, en forma muy especial, la peligrosidad del delincuente ${ }^{18}$. De esta forma, parece ser que los legisladores siguieron las experiencias comparadas más conservadoras en la materia.

También hay que mencionar que el proyecto original del ICP sólo contemplaba la remisión para las penas privativas de libertad y no para las restrictivas. Ello se debía a que el fundamento de la remisión concurría tratándose exclusivamente de penas cortas privativas de libertad ${ }^{19}$, en tanto las penas restrictivas de libertad solamente implicaban un límite a la libertad ambulatoria la que no quedaba del todo prohibida. Adicionalmente se podía dar como argumento que la remisión buscaba impedir el ingreso a la cárcel por las consecuencias perniciosas que ello implicaba para el penado y los beneficios económicos que suponía para el erario, mientras que las penas restrictivas no entraban en esa lógica toda vez que el sujeto no debía en caso alguno dar cumplimiento a pena en un contexto carcelario. No obstante lo anterior, la regulación finalmente comprendió

Jorge, La reincidencia en el sistema penitenciario chileno (Santiago, Fundación Paz Ciudadana, Universidad Adolfo Ibáñez y Hans Seidel Stiftung, 2012), pp. 34-36.

${ }^{16}$ GESCHE, Bernardo, La remisión condicional de la pena (Santiago, Editorial jurídica de Chile, 1975), p. 27.

${ }^{17}$ PeÑA, cit. (n. 8), p. 14.

${ }^{18}$ Gesche, cit. (n. 16), p. 27.

${ }^{19}$ NovoA, cit. (n. 3), p. 325 
a las penas restrictivas de la libertad, no existiendo un fundamento claro para su ampliación.

El segundo requisito, consistía en que el sujeto no debía haber sido condenado anteriormente por crimen o simple delito. La interpretación de esta circunstancia siempre fue restringida, toda vez que no se incluía las condenas por faltas ${ }^{20}$.

Como tercer requisito, se encontraba el que los antecedentes del reo y su conducta anterior, la naturaleza, modalidades y móviles determinantes del delito, permitieran presumir que no volvería a delinquir; criterio que, como veremos más adelante, se fue perpetuando en nuestra legislación, no obstante, la subjetividad y la introducción de criterios peligrosistas que el mismo supone.

Hay que mencionar que todos los requisitos encuentran su correlato en el derecho comparado, particularmente en los modelos seguidos por nuestro país y referenciados anteriormente (especialmente el caso español). En ellos, además de formularse un límite temporal basado en la pena restrictiva o privativa de libertad que se suspende, la pena alternativa estaba pensada única y exclusivamente a propósito de sujetos que delinquían por primera vez y que tienen antecedentes favorables, durante un plazo de prueba determinado.

Otorgada la remisión condicional de la pena, el condenado quedaba sujeto a un plazo de observación o más bien de prueba de enmienda, el cual era fijado por el tribunal, y el cual no podía ser inferior a un año ni superior a tres. En ese sentido, cabe destacar que al tratarse la remisión de una fórmula de suspensión, el plazo de observación podía ser superior al de la pena privativa de libertad suspendida, no exigiendo por tanto, un apego a criterios proporcionalistas. Conforme a la ley, durante ese plazo de observación el condenado debía cumplir una serie de condiciones o "reglas de conducta" que eran establecidas en la respectiva sentencia ${ }^{21}$ y transcurrido el período de tres años sin que la remisión condicional hubiere sido revocada, se tenía por cumplida la pena. Por su parte, en caso

${ }^{20}$ GeSCHE, cit. (n. 16), p. 28.

${ }^{21}$ Véase el art. 2 de la Ley N ${ }^{\circ} 7.821$. Esas reglas podían ser: 1) Residencia en un lugar determinado que podía ser propuesto por el reo; 2) Sujeción a la vigilancia de alguno de los Patronatos de Reos, debiendo observar las normas de conducta que éste le imparta; 3) Adoptar en un plazo fijo, que debía determinar el tribunal, una profesión, oficio, empleo, arte, industria o comercio, en caso que el condenado reo no tuviere medios conocidos y honestos de subsistencias, y; 4) Satisfacer la responsabilidad civil, costas y multas impuestas por la sentencia. El Tribunal, en caso de impedimento justificado, podía acordar este beneficio aun cuando no se hubiere satisfecho la responsabilidad civil, costas y multas, sin perjuicio de que se pudieran hacer efectivas en conformidad a las reglas generales. de incumplimiento de las reglas de conducta, el tribunal contaba discrecionalmente con la facultad de revocarla, mientras que en el caso que el sujeto hubiere cometido un nuevo delito de igual o mayor gravedad, la revocación operaba por el sólo ministerio de la ley ${ }^{22}$.

En términos de la supervisión de esta herramienta, el proyecto del ICP daba importancia al hecho que el control de esta institución no debía corresponder a organismos de carácter policial ni judicial, sino a un organismo especializado. Atendido lo anterior, finalmente la ley entregó la vigilancia a los Patronatos de Reos, dependientes de Gendarmería de Chile (en un inicio denominada Dirección General de Prisiones) ${ }^{23}$.

\section{LA EXTENSIÓN DEL ÁMBITO DE APLICACIÓN DE LA REMISIÓN CONDICIONAL (LEY No 17.642 DE 1972)}

Posteriormente, en el año 1972 se dictó la Ley $\mathrm{N}^{\circ} 17.642^{24}$, de 19 de abril, la cual modificó la Ley $\mathrm{N}^{\circ} 7.821$. La particularidad de esta nueva institucionalidad consistió en el aumento del plazo mínimo por el cual las penas podían ser remitidas, pues se incluyeron las penas privativas o restrictivas de libertad de hasta 3 años. Evidentemente con ello se buscó ampliar de manera importante el ámbito de aplicación de la remisión condicional.

La modificación obedeció a una moción del diputado comunista Teje$\mathrm{da}$, fundado en algunos trabajos realizados en la Universidad de Concepción por el Profesor Bernardo Gesche y sus colaboradores ${ }^{25}$, quienes habían establecido que de las tres herramientas de regeneración de delincuentes

${ }^{22}$ Véase el art. 3 de la Ley $\mathrm{N}^{\circ} 7.821$.

${ }^{23}$ El Patronato Nacional y los Patronatos locales de Reos, fueron creados por Decreto No 542, publicado en el Diario Oficial el 27 de febrero de 1943. Este organismo -denominado actualmente Departamento Post-penitenciario-, tiene por función apoyar la reinserción social y brindar apoyo post-penitenciario a la población de condenados, que egresa al medio libre, mediante el desarrollo de acciones de control e intervención (educación, trabajo, eliminación de antecedentes delictuales, etc.).

${ }^{24}$ De manera previa a esta modificación se dictó el Decreto Ley No 1969, de 19 de octubre de 1977, que buscaba un régimen especial de remisión condicional de la pena para miembros de las Fuerzas Armadas y Carabineros de Chile.

${ }^{25}$ La investigación, de naturaleza empírica, tuvo carácter regional, y consistió en la revisión de 9.956 fichas de condenados por los tribunales de Concepción, Lota, Coronel, Tomé, Los Ángeles y Yumbel, entre los años 1945 y 1967. Del total de fichas y en virtud de diversos filtros se analizaron finalmente 5.870 fichas. El estudio observó que la reincidencia de los condenados remitidos fue de un $12,45 \%$, en circunstancias que para la población general fue de 24,31\%. GESCHE, cit. (n. 16), p. 27. 
-remisión, indulto y libertad condicional-, la primera era la más eficaz en términos de la prevención de nuevos delitos, basado en un análisis de reincidencia de dichos instrumentos. En ese sentido, si bien hoy en día considerando los avances del conocimiento criminológico, resulta complejo argumentar la eficacia en la reducción de reincidencia de institutos que atienden a públicos objetivos disímiles y que tienden a seleccionar a los candidatos en base a determinados atributos ${ }^{26}$, vale la pena reconocer el esfuerzo realizado en la época de legislar apoyándose en data empírica.

La pretendida modificación planteaba la remisión de las condenas de hasta dos años ${ }^{27}$, empero, el Ministro de Justicia de la época planteó una indicación para que el plazo definitivo fuera de tres años, cuestión que posteriormente fue aprobada en la discusión en particular ${ }^{28}$

Las razones para este aumento del plazo obedecieron según dan cuenta las actas históricas, en la necesidad de evitar el pernicioso efecto de las penas privativas o restrictivas de la libertad de breve duración, en cuanto el sujeto encarcelado perdía en gran medida sus posibilidades de readaptación social. De esta forma, se buscó impedir que una persona de irreprochable conducta anterior y que hubiera llegado a delinquir por circunstancias

${ }^{26}$ Para una discusión sobre el particular, véase Morales - MUÑOZ - WelsCH FÁBREGA, cit. (n. 15), p. 38.

${ }^{27}$ El proyecto de ley fue presentado por Luis Tejeda Oliva y en su moción señalaba: "Desgraciadamente, la ley número 7821 de 29 de agosto de 1944, limita la facultad del Juez para remitir condicionalmente la pena únicamente cuando, cumpliéndose los demás requisitos, la sentencia aplica una pena restrictiva o privativa de la libertad que no exceda de un año.

Se aplica esa restricción, porque en la fecha de su dictación, esta ley importaba en Chile una innovación, cuyos resultados aún no se conocían; pero más de 25 de años de su aplicación han demostrado que se trata de un medio muy eficaz para la regeneración del delincuente.

Mientras en nuestro país la frecuencia con que se otorga la remisión condicional de la pena sólo es de un 12,93\%, en otros, llega a más del $60 \%$ del total de las condenas, y las legislaciones más modernas dejan al criterio del juez conceder o no este beneficio, teniendo en cuenta la peligrosidad del delincuente.

La opinión unánime de los magistrados a quienes he tenido oportunidad de consultar, es de opinión que debe ampliarse la facultad tan restringida que en la actualidad tienen en esta materia, a un mayor número de casos, para lo cual se hace indispensable modificar la ley vigente". Véase la Historia de la Ley No 17.642, el Diario de Sesión No 23 de la Cámara de Diputados, celebrada el 1 de diciembre de 1971 (Valparaíso, Biblioteca del Congreso Nacional Valparaíso, 1971), p. 1.

${ }^{28}$ Véase la Historia de la Ley No 17.642, Informe de la Comisión de Constitución, Legislación, Justicia, y Reglamento, recaído en el Proyecto de Ley de la Honorable Cámara de Diputados que modifica la Ley No 7.821, sobre remisión condicional de la pena, de fecha 21 de febrero de 1972 (Valparaíso, Biblioteca del Congreso Nacional), p. 2. ocasionales o accidentales, se viera obligado a sufrir el castigo adicional de alternar en un recinto carcelario de deprimentes condiciones materiales, con delincuentes habituales y en un ambiente que aniquilaba sus defensas morales y lo predisponía para persistir en la senda delictiva ${ }^{29}$.

$\mathrm{Al}$ respecto, reparan Solari y Tudela, que la Ley $\mathrm{N}^{\circ} 17.642$ al haber extendido el límite de las penas que podían ser objeto de remisión (3 años) "el instituto perdió la pureza doctrinal con que fue concebido, esto es, como un medio tendiente a reemplazar las penas cortas privativas o restrictivas de libertad, no pudiendo calificarse de tales las penas que pueden llegar hasta tres años" 30 . Cabe al respecto criticar los planteamientos de los autores, en la medida que como se expuso, la experiencia comparada ya mostraba su aplicación en penas superiores de un año y donde el argumento acerca de la pureza doctrinal, no parece suficiente para oponerse a su ampliación. Por su parte, los mismos autores siguiendo a Peña ${ }^{31}$ alegaron la pérdida de “armonización” entre la condena condicional pensada para aquellas penas no superiores a un año de duración, y la libertad condicional establecida para penas superiores a ese tiempo, habiéndose roto la correspondencia entre ambas instituciones; planteamientos que también merecen ser criticados en la medida que se trata de institutos que operan en momentos distintos, la primera más bien inserta dentro de la fase de juzgamiento y la segunda en sede de ejecución penal, habiendo transcurrido al menos la mitad de la condena.

También esta nueva normativa incrementó el plazo de observación del

29 Se aprobó la indicación por mayoría de la Comisión del Senado, con la oposición de dos senadores quienes si bien estaban de acuerdo en el aumento del plazo de uno a tres años, opinaron que el sistema de vigilancia por el cual se sometía al individuo durante el período de observación ante Patronato de Reos, era deficiente, por cuanto se limitaba a la mera formalidad de una firma mensual, por lo cual estimaban que en forma previa se debía garantizar que el beneficio fuere concedido en forma seria de manera que produjere los resultados esperados. A raíz de las observaciones formuladas acerca de la eficacia con que los Patronatos de Reos cumplirían su labor de supervigilancia respecto de los favorecidos con la remisión, se aprobó una indicación destinada a hacer exigible la presentación anual ante esos Servicios, por parte de los condenados, de un Certificado de Antecedentes, a fin de dar mayores posibilidades de observación y control. Véase la Historia de la Ley No 17.642, Informe de la Comisión de Constitución, Legislación, Justicia, y Reglamento, recaído en el Proyecto de Ley de la Honorable Cámara de Diputados que modifica la Ley No 7.821, sobre remisión condicional de la pena, de fecha 21 de febrero de 1972 (Valparaíso, Biblioteca del Congreso Nacional).

${ }^{30}$ Solari, Tito - Tudela, Ximena, Remisión condicional de la pena, reclusión nocturna y libertad vigilada. (Comentario sobre el texto legal), en Revista de Derecho de la Pontificia Universidad Católica de Valparaíso 7 (1983), pp. 241-264 y 245.

${ }^{31}$ Peña, cit. (n. 8), p. 15. 
condenado al Patronato de Reos a un plazo mínimo de 1 año y máximo de 5, el que para el caso concreto debía ser igual al doble del quantum de la pena privativa de libertad a la cual el sujeto fue condenado, estableciendo por tanto reglas más objetivas para la determinación del plazo de observación. Transcurrido este sin que se hubiese revocado el beneficio, a modo de ficción legal, se tenía por cumplida la pena originalmente impuesta, debiendo así declararlo el tribunal que hubiera dictado la sentencia en primera instancia.

Finalmente, bajo el imperio de esta ley, si durante el período de prueba el condenado quebrantaba algunas de las condiciones impuestas en la sentencia, el tribunal podía revocar la suspensión de la pena a petición del Patronato de Reos respectivo, debiendo cumplir íntegramente la pena originalmente impuesta. Por otra parte, se contemplaba otra forma de revocación ipso facto y tenía lugar cuando dentro del período de tres años, plazo fijo previsto por el legislador, el beneficiado era declarado reo por resolución ejecutoriada por un nuevo delito de igual o mayor gravedad. Con ello, claramente se quebrantaba el principio de inocencia, puesto que era menester no la declaración de culpabilidad por una sentencia de término, sino la encargatoria de reo de aquel entonces o la mera formalización de la investigación de los tiempos actuales.

\section{LA MASIFICACIÓN DE LAS MEDIDAS ALTERNATIVAS}

(LEY No 18.216 DE 1983)

No fue sino hasta el año 1983, propiciada por un mensaje del ejecutivo, donde se gestó la modificación normativa más importante en lo que a penas alternativas a la privación de libertad se refiere. En efecto, ese año se dictó la Ley No 18.216, de 14 de mayo, sobre "Medidas alternativas a las penas privativas o restrictivas de libertad". Se destaca en la historia legislativa que el proyecto se sustentó en la tendencia en materia criminológica de la época, que sólo recomendaba en forma muy reducida la aplicación de penas privativas o restrictivas de la libertad, impulsando, en cambio, el tratamiento en el medio libre con la activa participación de la sociedad ${ }^{32}$; no necesariamente reduciendo su utilización respecto de las penas cortas de prisión. En la historia de la ley, en una interacción de la Subsecretaria de Justicia de la época y el Almirante Merino, se develó cuál era la ratio legis detrás de estas alternativas. No era otra que reconocer a la cárcel como

${ }^{32}$ Véase la Historia de la Ley No 18.216, Informe de Secretaría de Legislación de 22 de junio de 1982 (Valparaíso, Biblioteca del Congreso Nacional), p. 10. institución de contagio criminógeno y que el medio libre era el apto para alcanzar la reinserción social y evitar la reincidencia futura ${ }^{33}$.

El proyecto habría sido gestado por el profesor de criminología de la Universidad de Chile, Marco A. González, el cual sostenía el argumento respecto de la necesidad del tratamiento y rehabilitación del condenado, entendiendo que había "llegado momento de ir reemplazando los barrotes y destruir el mito, que todavía persiste en algunos países, de creer que la prisión constituye la panacea universal contra el delito", pues en su concepto "la prisión ha fracasado como sistema en sus cuatro siglos de funcionamiento" 34 .

Las virtudes de este nuevo ordenamiento venían dadas porque no solo se recoge la remisión condicional de la pena como pretéritamente era entendida, sino también se consagraron dos nuevas medidas, ampliando el abanico de formas alternativas a la cárcel: la reclusión nocturna y la libertad vigilada. No obstante, esta modificación se aleja del sentido original de la remisión condicional de la pena concebida sólo para reemplazar penas cortas privativas de libertad, extendiéndose ahora a penas más largas (de hasta 5 años $)^{35}$. A continuación, se analizan someramente cada una de las medidas alternativas propuestas:

\section{La remisión condicional de la pena}

El primero de los institutos, la remisión condicional de la pena, consistía, según lo que estipulaba la ley en su versión original, en la suspensión del cumplimiento de la pena privativa de libertad y la discreta observación y asistencia del condenado por la autoridad administrativa durante cierto tiempo o "plazo de observación". Dicho plazo no debía ser inferior a la pena originalmente impuesta, con un mínimo de un año y un máximo de tres. Esta suspensión no dejaba al condenado libre de toda exigencia, puesto que lo dejaban sometido a un régimen de observación y asistencia,

${ }^{33}$ Véase la Historia de la Ley No 18.216, Acta No 28 de Sesión de la Junta de Gobierno de 26 de octubre de 1982 (Valparaíso, Biblioteca del Congreso Nacional), p. 22 ss.

${ }^{34}$ González, Berendique - Marco, Revista Ercilla 2469, en Solari - Tudela, cit. (n. 30), p. 262.

35 SOlari - Tudela, cit. (n. 30), p. 246: "no se trata de penas que puedan ser calificadas de cortas, si se considera que en algunos casos la medida alternativa puede favorecer a una persona condenada a una pena que llegue a 5 años, (...) y por otro lado, tampoco siempre beneficia al delincuente primario, pues puede otorgarse el beneficio alternativo de reclusión nocturna, a personas que han sido anteriormente condenadas". 
ya no del Patronato Nacional de Reos, sino que a cargo de la Sección de Tratamiento del Medio Libre, dependiente de Gendarmería de Chile ${ }^{36}$.

El primer requisito que hacía procedente este beneficio era que la pena privativa o restrictiva de libertad impuesta por la sentencia condenatoria no excediera de 3 años $^{37}$. Sobre este requisito, como ya se señaló en relación con la anterior regulación de la remisión, reparaba la doctrina en lo peculiar que resultaba aplicar este beneficio a las penas restrictivas de libertad, en tanto el objetivo sólo era evitar los efectos nocivos de las penas privativas de corta duración ${ }^{38}$. Asimismo, también replicando anteriores críticas, se le reprochó su extensión temporal (de un año a 3), en la medida que implicaba un abandono de los fundamentos primitivos del beneficio, pues una pena de más de un año ya no era lo que tradicionalmente se consideraba como una pena "corta", a lo que se sumaba que en un lapso de hasta tres años se podía disponer de tiempo para emitir un diagnóstico sobre la personalidad del sujeto y someterlo a un tratamiento resocializador ${ }^{39}$.

El segundo requisito que suponía la procedencia de la medida era que el reo no hubiera sido condenado anteriormente por crimen o simple delito. La condena anterior por falta no era un obstáculo para el cumplimiento de este requisito ${ }^{40}$. Incluso para alguna doctrina la condena por delito culposo (cuasidelito) o una pena prescrita conforme las reglas generales ${ }^{41}$ también suponía la procedencia de la medida en atención a dicho requisito.

Por último, la remisión procedía si los antecedentes personales del reo, su conducta anterior y posterior al hecho punible y la naturaleza, modalidades y móviles determinantes del delito permitían presumir que este no volvería a delinquir ${ }^{42}$. Esta fórmula, en términos simples, suponía una

36 En el año 1984 se crearon las primeras "Secciones de Tratamiento en el Medio Libre" con el objeto de cubrir la demanda que ocasionare la aplicación de la Ley $\mathrm{N}^{\circ}$ 18.216. En la actualidad se denominan Centros de Reinserción Social, siendo estos últimos creados en virtud del decreto Ley de Justicia $\mathrm{N}^{\circ} 1.771$ de 1992, el cual estableció un nuevo Reglamento de Establecimientos Penitenciarios. Hofer, María Eugenia, Medidas alternativas a la reclusión en Chile, Conceptos, en Fundación Paz Ciudadana 4 (2008), pp. 1-12 y 3.

${ }^{37}$ Véase el art. 5 de la versión original de la Ley $\mathrm{N}^{\circ} 18.216$.

${ }^{38}$ NovoA, cit. (n. 3), p. 326 y ss.; CurY, cit. (n. 4), p. 730; ETCHEberry, Alfredo, cit. (n.11), p. 201.

${ }^{39}$ Cury, cit. (n. 4), p. 731

${ }^{40}$ Cury, cit. (n. 4), p. 731; Etcheberry, cit. (n. 11), p. 201; Ortiz Quiroga, Luis - Arévalo, Javier, Las consecuencias jurídicas del delito (Santiago, Editorial Jurídica de Chile, 2013), p. 189.

${ }^{41}$ Ortiz - Arévalo, cit. (n. 40), p. 189.; Politoff, Sergio - Matus, Jean Pierre Ramírez, María Cecilia, Lecciones de Derecho penal chileno. Parte General (2a edición, Santiago, Editorial Jurídica de Chile, 2003), p. 545.

${ }^{42}$ Jurisprudencia de la época indicaba que para la concesión del beneficio se prognosis de ausencia de peligrosidad del sujeto, aun cuando el término en sí no es utilizado dado implicancias doctrinales y políticas ${ }^{43}$. Acá el requisito no solo estaba referido a los posibles antecedentes penales, sino que la presunción se refiere a que no vuelva a delinquir en general, no limitada a ser reincidente en el mismo delito ${ }^{44}$.

Finalmente, se exigía como último requisito de procedencia el que si las circunstancias de las letras b) -ausencia de condenas previas- y c) -prognosis de ausencia de peligrosidad-, hicieren innecesario un tratamiento o la ejecución efectiva de la pena. Este requisito tenía por objeto distinguir aquellas situaciones donde era aconsejable que se cumpla la remisión condicional de aquellas otras medidas alternativas, o por el contrario, era recomendable la ejecución de la pena privativa o restrictiva de libertad ${ }^{45}$.

Como se señaló, los dos primeros requisitos son prácticamente idénticos a los contenidos en la Ley $\mathrm{N}^{\circ}$ 17.642. Con respecto al tercer requisito existía una leve diferencia, debido a que requería considerar la conducta posterior, cosa que no era exigida en la pretérita ley. El cuarto requisito comportaba una entera novedad, que implicaba que el sentenciador debía verificar que el cumplimiento de la pena privativa de libertad originalmente impuesta o la realización de un tratamiento para el penado eran innecesarios de ejecutar ${ }^{46}$. Sin embargo, a diferencia del caso de la libertad vigilada, no se contempló la posibilidad para la judicatura de solicitar la elaboración de informes psicosociales o de otra naturaleza, que le permitieren contar con insumos para decidir precisamente del supuesto de ausencia de peligrosidad o de la ineficacia del tratamiento para el caso concreto.

El beneficio podía concederse de oficio o a petición de parte. Al concederse el beneficio, el juez debía imponer al condenado una serie de condiciones o reglas de conducta que debía cumplir ${ }^{47}$. El tribunal, en caso de

requería que los antecedentes personales del reo y su conducta anterior, la naturaleza y móviles determinantes del delito permitan presumir que no volverá a delinquir vale decir, la presunción arranca tanto de los favorables antecedentes conductuales del reo como de las características propias de la acción punible (Revista Fallos del Mes No 278, 198) p. 620.

${ }^{43}$ NovoA, cit. (n. 3), p. 327; Cury, cit. (n. 4), p. 732.

${ }^{44}$ ETCHEBerRy, cit. (n. 11), p. 201.

${ }^{45}$ Cury, cit. (n. 4), p. 732; Etcheberry, cit. (n. 11), p. 202

${ }^{46}$ Solari y Tudela al respecto reparan que a propósito del tratamiento no queda claro en qué consiste el mismo, y si la necesidad de tratamiento debiera conducir a la imposición de una libertad vigilada, que es la única medida que lo contempla. SOLAR - Tudela, cit. (n. 30), p. 250

${ }^{47}$ Véase el art. 24 de la versión original de la Ley $\mathrm{N}^{\circ} 18.216$. Las condiciones o requisitos podían ser: a) Residencia en un lugar determinado, que podía ser propuesto por el condenado. La residencia, podía ser cambiada, en casos 
impedimento justificado, podía prescindir de esta exigencia, sin perjuicio que se persiguieran estas obligaciones en conformidad a las reglas generales. Como apuntan Etcheberry y Cury, el no pago de la multa podía terminar mediante su conversión en pena privativa de libertad, oponiéndose a los fines de la medida ${ }^{48}$.

En caso de quebrantamiento, el que se producía cuando se incumplía dentro del período de observación alguna de las condiciones indicadas, la sección de tratamiento en el medio libre debía solicitar al juez sentenciador que revocara la remisión. Frente a aquello, el tribunal podía disponer el cumplimiento de la pena originalmente impuesta o su conversión en reclusión nocturna, según fuere aconsejable ${ }^{49}$. También se producía el quebrantamiento cuando se cometía nuevo crimen o simple delito por parte del beneficiado durante el período de observación. En este caso, la revocación se producía por el solo ministerio de la ley, y su efecto era el de obligar al cumplimiento efectivo del total de la pena inicialmente impuesta o, si procediere dictaba la ley, de una medida alternativa equivalente a toda su duración ${ }^{50}$

\section{La reclusión nocturna}

Por su parte, la reclusión nocturna era una forma de cumplimiento parcial, pero efectiva de la pena privativa de libertad, la que se ejecutaba mediante el encierro en establecimientos especiales de Gendarmería de Chile, desde las 22 horas de cada día hasta las 6 horas del día siguiente ${ }^{51}$. Los requisitos para la procedencia de esta también denominada medida eran: a) que la pena privativa o restrictiva de libertad no excediera de 3 años ${ }^{52}$; b) que el reo no hubiera sido condenado anteriormente por cri-

especiales, según calificación efectuada por la sección de tratamiento en el medio libre de Gendarmería de Chile; b) sujeción al control administrativo y asistencia a la sección correspondiente de Gendarmería de Chile, en la forma que precisaba el reglamento. Además, esta debía recabar anualmente al efecto, un certificado de antecedentes prontuariales; $c$ ) ejercer, dentro del plazo y bajo las modalidades que determinara la sección de tratamiento en el medio libre de Gendarmería de Chile, una profesión, oficio, empleo, arte, industria o comercio, si el condenado carecía de medios conocidos y honestos de subsistencia y no poseía calidad de estudiante, y d) satisfacción de la indemnización civil, costas y multas impuestas por la sentencia.

${ }^{48}$ ETCHeberRy, cit. (n. 11), p. 203; CURY, cit. (n. 4), p. 734

${ }^{49}$ Véase el art. 6 de la versión original de la Ley $\mathrm{N}^{\circ} 18.216$

${ }^{50}$ Véase el art. 27 de la versión original de la Ley $\mathrm{N}^{\circ} 18.216$

${ }^{51}$ Véase el art. 7 de la versión original de la Ley $\mathrm{N}^{\circ} 18.216$.

52 Para Cury nada obsta la procedencia de esta medida respecto de penas más prolongadas. En efecto, para el citado autor, esta medida cumple efectivamente una función preventivo general -aunque con una modalidad que atenúa los men o simple delito o lo hubiera sido a una pena privativa o restrictiva de libertad que no excediera de 2 años o a más de una, siempre que en total no excediera ese límite, y c) si los antecedentes personales del reo, su conducta anterior y posterior al hecho punible y la naturaleza, modalidades y móviles determinantes del delito permitieran presumir que la medida de reclusión nocturna lo disuadirán de cometer nuevos delitos ${ }^{53}$. Como menciona Cury, una vez más aparece aquí el eufemismo de la peligrosidad como criterio de concesión de la medida y, además, se hace una referencia ambigua a la disuasión, respondiendo el requisito tanto a las funciones de prevención general como especial ${ }^{54}$.

Los condenados a reclusión nocturna debían satisfacer la indemnización civil, costas y multas impuestas por la sentencia, en los mismos términos regulados a propósito de la remisión condicional (la letra d) del art. $5^{\circ}$ ), lo que implicaba que el tribunal en caso de impedimento justificado podía prescindir de esta exigencia, sin perjuicio de su persecución conforme a las reglas generales ${ }^{55}$.

En caso de quebrantamiento, el cual debía ser grave o reiterado y sin causa justificada, facultaba al tribunal de oficio o a petición de Gendarmería de Chile a revocarla, ordenando el cumplimiento de la pena privativa o restrictiva de libertad por el saldo no cumplido ${ }^{56}$. Para los efectos del cómputo, la ley preveía una regla de conversión de la pena inicialmente impuesta indicando que se computaba una noche por cada día de duración de esa pena ${ }^{57}$.

efectos negativos de la privación restricción de libertad-, lo que implica también una concesión legítima y deseable de las finalidades de prevención especial. CURY, Enrique, cit. (n. 4), p. 739; asintiendo con Cury se manifiestan OrTiZ - ArÉVAlo, cit. (n. 40), p. 96

${ }^{53}$ Véase el art. 8 de la versión original de la Ley $N^{\circ} 18.216$.

${ }^{54}$ CurY, cit. (n. 4), p. 739, para quien: "procede aplicar la medida tanto cuando el reo es un sujeto peligroso al cual ella basta para resocializar, como cuando es un ocasional a quien esa forma de ejecución alejará de tentaciones futuras."

${ }^{55}$ Véase el art. 12 de la versión original de la Ley $\mathrm{N}^{\circ} 18.216$.

${ }^{56}$ Véase el art. 11 de la versión original de la Ley $\mathrm{N}^{\circ}$ 18.216. A su vez, el art. 12 del Reglamento definía algunos conceptos jurídicos importantes para entender cuándo existía quebrantamiento en el art. 11 de la ley. Así, definía que se debía entender por "grave", entendiéndose por tal: "...la circunstancia de no presentarse al reo, al respectivo establecimiento, a cumplir la medida de reclusión nocturna"; y también define "reiterado", señalando: "Constituirán quebrantamiento reiterado todas aquellas conductas que tiendan a perturbar el cumplimiento de la reclusión nocturna, o que signifiquen su cumplimiento parcial, tales como incurrir en atrasos en las horas de entrada y salida, o presentarse a la unidad penal en manifiesto estado de ebriedad en dos o más oportunidades".

${ }^{57}$ Véase el art. 9 de la versión original de la Ley $\mathrm{N}^{\circ} 18.216$. 
La reclusión nocturna presentaba diferencias palmarias con la remisión condicional de la pena y la libertad vigilada que revisaremos más adelante. Primero, no era una medida "alternativa a la privación o restricción de libertad", puesto que implicaba una privación de libertad efectiva por un tiempo determinado. Para Cury estábamos frente a una institución que no implicaba una suspensión de la ejecución de la pena como las otras medidas, sino una manera de cumplirla en una forma que atenuaba las limitaciones de la libertad impuesta al condenado. Ello se confirmaría en palabras de este autor, ya que en caso de revocación del beneficio, el afectado sólo debía cumplir el resto de la pena originalmente impuesta (arts. 11 y 27 inc. $\left.2^{\circ}\right)^{58}$, a diferencia del resto de las medidas, que en caso de ser revocadas correspondía el cumplimiento íntegro de la pena originalmente impuesta. En el mismo sentido, atendido dicho efecto, Matus planteaba que la reclusión nocturna correspondería a una pena sustitutiva, en virtud de la cual se sustituía por completo la pena privativa de la libertad, siendo equívoca su correspondencia con la denominación de "medidas alternativas" 59

Esta diferencia que hacía la ley, a propósito de los abonos a la pena privativa de libertad, entre, por un lado la remisión condicional de la pena y la libertad vigilada, y por otro lado la reclusión nocturna, nos lleva a sostener que la reclusión nocturna no era un beneficio sino una pena en el su sentido natural, siendo dudoso que hayamos estado frente a un denominado beneficio ${ }^{60}$

\section{La libertad vigilada}

Finalmente, el último beneficio contemplado por esta ley era la libertad vigilada. Esta era concebida como una libertad a prueba que tendía a un tratamiento intensivo e individualizado para el penado. Se trataría de la medida con mayor contenido preventivo especial ${ }^{61}$ considerando que es la única medida que considera acceso a tratamiento para abordar la conducta delictiva. Otros autores indicaban que era una medida altamente selectiva

${ }^{58}$ CURY, cit. (n. 4), p. 738; en términos similares se manifiestan OrTIZ - ARÉVALO, cit. (n. 40), p. 194; Solo en el sentido de que se trata de un encierro atenuado se manifiestan Politoff, Sergio - Matus - RamíREZ, cit. (n. 41), p. 548; desconoce que sea una suspensión de la pena privativa o restrictiva de libertad, sino una modalidad de su cumplimiento, que sería más benigna Garrido Montt, Mario, Derecho penal. Parte General (2a edición, Santiago, Editorial Jurídica de Chile, 2007), I, p. 363.

${ }^{59}$ Matus, Jean Pierre, Medidas alternativas a las penas privativas de la libertad en una futura reforma penal chilena, en Boletín Jurídico del Ministerio de Justicia 2 (2003), pp. 187-198.

${ }^{60}$ ETCheberry, cit. (n. 11), p. 213

${ }^{61}$ Ortiz - Arévalo, cit. (n. 41), p. 196. por la extensión de la pena requerida para su imposición ${ }^{62}$. Las diferencias con el resto de medidas venían dadas porque permitía su aplicación a penas más largas y las obligaciones impuestas al régimen de observación eran más estrictas ${ }^{63}$

Sin embargo, Cury más bien la concebía como una modalidad de la remisión condicional de la pena con ciertas características de la anglosajona probation ${ }^{64}$, en la medida que por un lado importaba una suspensión del cumplimiento de una pena privativa o restrictiva de libertad y, por el otro, sujetaba al condenado a la vigilancia de un oficial de libertad que cumplía además de funciones de control, de apoyo y consejo encaminadas a la resocialización del sujeto.

La libertad vigilada procedía, de conformidad con lo establecido en la ley, en los siguientes supuestos copulativos: $a$ ) si la pena privativa o restrictiva de libertad impuesta por la sentencia condenatoria era superior a 2 años y no excedía de 5 . Como se aprecia, tratándose de penas entre 2 años y un día y 3 años, estas podían ser objeto tanto de remisión condicional de la pena como de este beneficio ${ }^{65} ; b$ ) que el condenado no fuese condenado anteriormente por crimen o simple delito, y $c$ ) si los informes sobre antecedentes sociales y características de personalidad del reo, su conducta anterior y posterior al hecho punible y la naturaleza, modalidades y móviles determinantes del delito permitían concluir que un tratamiento en libertad aparecía eficaz y necesario, en el caso específico, para una efectiva readaptación y resocialización del beneficiado. Este informe era evacuado por Gendarmería y se conocía como "informe presentencial" 66 .

Puede advertirse que este último requisito era similar al de la remisión condicional de la pena, sólo que en esta bastaba con que los elementos de juicio mencionados por la ley permitieran al juez presumir que el condenado no volvería a delinquir, en tanto que en el caso de la libertad vigilada, se admitía la posibilidad que el sujeto delinquiera nuevamente, pero se estimaba que la fórmula más eficaz para impedirlo era tratarlo en libertad, sometido a vigilancia y obligaciones en cuanto a todo su régimen de vida ${ }^{67}$. De esta forma, se entendía que el tratamiento era necesario cuan-

\footnotetext{
${ }^{62}$ Politoff - Matus - Ramírez, cit. (n. 41), p. 547.

${ }^{63}$ ETCHeberRY, cit. (n. 11), p. 204

${ }^{64}$ CurY, cit. (n. 4), p. 735; de manera similar Garrido, cit. (n. 58), p. 359

${ }^{65}$ Cury, cit. (n. 4), p. 736; Etcheberry, cit. (n. 11), p. 205; Ortiz - Arévalo, cit. (n. 40), p. 197.

${ }^{66}$ Véase el art. 15 de la versión original de la Ley $\mathrm{N}^{\circ} 18.216$.

${ }^{67}$ Etcheberry, cit. (n. 11), p. 205.
} 
do el sujeto era peligroso y se esperaba que la aplicación del tratamiento en libertad contribuyera a remover esa característica de su personalidad ${ }^{68}$.

Para esto, el tribunal debía establecer un plazo de tratamiento y observación que no debía ser inferior al de duración de la pena, con un mínimo de 3 años y un máximo de 6 . Como se observa en este caso, la ley hacía referencia al plazo de "tratamiento y observación", a diferencia de la remisión condicional, que sólo sometía a un plazo de "observación", dada la ausencia de tratamiento. Cabe notar que la ley, particularmente en el caso de la libertad vigilada, permitía un plazo superior al de pena originalmente impuesta pudiendo incluso llegar a 6 años, solución que si bien pudiere ser percibida como una vulneración del principio de proporcionalidad, tenía sentido bajo una lógica correccionalista, en el cual el fin era la rehabilitación del condenado, pudiendo incluso concretarse más allá de los límites previstos por la ley ${ }^{69}$.

Esta medida se ejecutaba bajo la supervisión y vigilancia del delegado de libertad vigilada, funcionario dependiente de Gendarmería de Chile ${ }^{70}$. El tribunal al conceder el beneficio debía imponer alguna de las condiciones que indicaba la ley ${ }^{71}$ y también durante el período de ejecución, se le autorizaba al juez para ordenar que el beneficiado fuese sometido a los exámenes médicos, psicológicos o de otra naturaleza que aparecieran necesarios $^{72}$.

En cuanto a la ejecución de la libertad vigilada, en caso de quebrantamiento de algunas de las condiciones impuestas por el tribunal, o la desobediencia grave o reiterada y sin causa justa a las normas de conducta impartidas por el delegado, el tribunal se encontraba facultado para revocar el beneficio. En tal caso, éste podía disponer el cumplimiento de las penas inicialmente impuestas o su conversión, si hubiera procedido, en reclusión nocturna ${ }^{73}$.

La Ley $\mathrm{N}^{\circ} 18.216$ contempló para las tres medidas alternativas a la privación o restricción de libertad antes analizadas, su revocación por el solo ministerio de la ley en el caso de la comisión de nuevo crimen o simple delito durante el período de cumplimiento del beneficio ${ }^{74}$. Como

\footnotetext{
${ }^{68}$ CuRY, cit. (n. 4), p. 736
}

${ }^{69}$ Sobre las manifestaciones del "ideal rehabilitador" en la legislación anglosajona del pasado siglo véase Garland, David, La cultura del control (Madrid, Gédisa, 2001), pp. 71 ss.

${ }^{70}$ Véase el arts. 16, 20 y 23 de la versión original de la Ley $\mathrm{N}^{\circ} 18.216$.

${ }^{71}$ Véase el art. 17 de la versión original de la Ley $\mathrm{N}^{\circ} 18.216$.

${ }^{72}$ ETCHEBERRY, cit. (n. 11), pp. 206-207.

${ }^{73}$ Véase el art. 19 de la versión original de la Ley $\mathrm{N}^{\circ} 18.216$.

${ }^{74}$ Véase el art. 26 de la versión original de la Ley $\mathrm{N}^{\circ} 18.216$. se señaló anteriormente, en caso de revocación de la remisión condicional de la pena o de la libertad vigilada, el condenado debía cumplir la pena privativa de libertad originalmente impuesta. Esto implicaba que en caso de cumplimiento del beneficio de manera parcial, por ejemplo, no había abono alguno, toda vez que ambas medidas eran concebidas, como fórmulas de suspensión, de tal manera que frente al incumplimiento de las condiciones se retomaba la pena privativa. La situación era diferente en el caso de la reclusión nocturna, la que, por tratarse de una sustitución de una pena privativa por otra de igual naturaleza, la ley contemplaba la posibilidad de abonar el tiempo de cumplimiento del beneficio a la pena privativa de libertad originalmente impuesta ${ }^{75}$.

Por otro lado, en el caso del transcurso del tiempo de observación fijado por el tribunal, sin revocación del beneficio, la ley tenía por cumplida la pena privativa de libertad originalmente impuesta ${ }^{76}$. Esto se traducía en la existencia de dos tipos de cumplimiento. Uno denominado "satisfactorio", cuando el condenado daba cumplimiento a la pena; e "insatisfactorio", cuando esta se daba por cumplida por el transcurso del tiempo, aun cuando el condenado no hubiera dado inicio o hubiera abandonado su ejecución. Si bien los fundamentos que parecen haber inspirado tal norma radican en la necesidad de entregar certeza jurídica, la solución entregada por la misma generó una amplia y nutrida jurisprudencia de los Tribunales, respecto de si el sentenciado tenía que haber cumplido satisfactoriamente o no el beneficio para tener por cumplida la pena privativa.

Como corolario de la evolución histórica de las alternativas en su primer período (hasta la reforma de la Ley No 18.216), podemos destacar que su génesis obedeció a las críticas a las penas privativas y restrictivas de libertad de corta duración y su insuficiencia para cumplir las expectativas esperadas. Particularmente la imposibilidad de satisfacer la función de la pena de procurar la rehabilitación del condenado y evitar el contagio criminógeno de este. Además, se encuentran justificaciones de tipo económico, relativas a los costos de la cárcel y los efectos en la vida social de los penados, y paulatinamente se origina un reconocimiento de las alternativas como sanciones idóneas en sí mismas, desde la óptica de la prevención especial positiva.

\footnotetext{
${ }^{75}$ Véase el art. 27 de la versión original de la Ley N 18.216.
}

${ }^{76}$ Véase el art. 28 de la versión original de la Ley $\mathrm{N}^{\circ} 18.216$. 


\section{Concepción actual de las penas alternativas: penas sustitutivas}

El 27 de junio de 2012 se publicó en el diario oficial la Ley № 20.603 que modificó la Ley No 18.216, que establece medidas alternativas a las penas privativas o restrictivas de libertad, sistema de penas alternativas a la cárcel actualmente vigente en el país ${ }^{77}$. Cabe hacer presente que la propia ley postergó su entrada en vigencia, considerando una implementación gradual de la misma a contar de la fecha de la dictación de su reglamento con fecha 27 de Diciembre de $2013^{78}$.

Esta reforma tuvo origen en un mensaje del Ejecutivo del año 2008, el cual era más bien modesto en sus pretensiones, pues mantenía la naturaleza jurídica de las alternativas como "beneficios", apostando por la ampliación del catálogo a la reparación del daño y a los trabajos en beneficio de la comunidad -alternativas ya existentes en otras legislaciones nacionales-, junto con la regulación de reglas más estrictas para el caso de incumplimiento de las medidas.

Dicho proyecto de ley, fue criticado por algunos expertos, toda vez que de acuerdo a su visión, persistían en él "muchas franjas de impunidad en la Ley $N^{\circ} 18.216$ de las que no se hacía cargo"79 junto con crear "nuevas franjas de impunidad" 80 . En sintonía con lo anterior, los diputados integrantes de la Comisión de Constitución de la cámara también cuestionaron el proyecto, pues por un lado, les parecía relevante extender la utilización del monitoreo electrónico a propósito de la cantidad de condenados a libertad vigilada que se encontraban cumpliendo condena por delitos sexuales, y por el otro, restringir la posibilidad de imponer la reclusión nocturna para el caso de multireincidentes ${ }^{81}$.

Lo anterior conllevó a que con fecha 13 de octubre de 2009 el Ejecutivo presentara una indicación sustitutiva del proyecto, que, como su nombre indica, supone sustituir completamente el texto original por uno nuevo. El aspecto más relevante de esta nueva propuesta fue el cambio de denominación de "medidas alternativas" a "penas alternativas", no obstante que

${ }^{77}$ El proyecto de ley, ingresado a tramitación legislativa el 31 de marzo de 2008, tuvo una tramitación extensa, de casi 4 años, durante la cual sufrió importantes cambios, a través de indicaciones del ejecutivo y mociones parlamentarias.

${ }^{78}$ Decreto $N^{\circ} 1120$ del Ministerio de Justicia que contiene el Reglamento de la Ley $\mathrm{N}^{\circ} 18.216$.

${ }^{79}$ Historia de la Ley $N^{\circ} 20.603$ (Valparaíso, Biblioteca del Congreso Nacional, 2012), p. 63.

${ }^{80}$ Ibid.

${ }^{81}$ Ibid, p. 64 en su art. $1^{\circ}$ continuaba considerándolas como fórmulas de suspensión de las penas privativas o restrictivas de la libertad ${ }^{82}$.

Presentada esta nueva indicación, el proyecto avanzó lentamente considerando el escenario de elecciones presidenciales. Llegado el nuevo gobierno, este analizó el proyecto y a pocos meses de iniciado presentó una nueva indicación sustitutiva en agosto de 2010, profundizando en las reformas a la Ley $\mathrm{N}^{\circ} 18.216$ propuestas por el anterior gobierno.

La indicación presentada mantuvo la nueva denominación entregada de "penas", pero las denominó "penas sustitutivas". Lo anterior con el objeto de precisar que no se está frente a un "beneficio" otorgado al condenado, sino que frente a una sanción, que a su vez se impone en forma sustitutiva a la pena privativa de la libertad originalmente impuesta, pudiendo ser revocada en el evento ser incumplida ${ }^{83}$.

Dentro de los principales cambios, se propuso la regulación de un catálogo de exclusión de aquellos delitos respecto de los cuales no serían procedentes las penas sustitutivas. Con esto, se buscó ampliar el catálogo de improcedencia ya existente, pudiendo distinguirse entre una exclusión general y una específica.

En concreto, la exclusión general que procede respecto de todas las sustitutivas, junto con mantener las exclusiones ya existentes, buscó ampliarlas a los casos de autores consumados de los delitos de secuestro calificado, sustracción de menor, violación propia, homicidio simple y calificado y respecto de los delitos contemplados en la Ley $\mathrm{N}^{\circ} 18.314$ que determina las conductas calificadas como terroristas.

Sin embargo, la propia norma contempla una excepción para el caso del condenado respecto del cual la sentencia hubiere reconocido que hubiere obrado amparado en una eximente incompleta de responsabilidad penal del art.10 del Código Penal, en los términos del art. 11 No 1 del mismo Código, buscando abordar casos en que pudiese constatarse una necesidad de pena inferior atendidas las circunstancias ${ }^{84}$.

Como parte del criterio de exclusión específico, se contemplaba el caso de los autores de delitos consumados de robo por sorpresa que fueren reincidentes respecto de delitos de igual naturaleza y también el de los autores

${ }^{82}$ Dicha indicación no será analizada en profundidad, toda vez que gran parte de su contenido fue mantenido en la tramitación de la indicación sustitutiva presentada el 18 de agosto de 2010, el cual sí será objeto de análisis y contrastes con el proyecto aprobado.

${ }^{83}$ Ibid, p. 21.

${ }^{84}$ Sobre la aplicación de esta regla para el caso de la atenuación extraordinaria del art. 73 CP, véase Defensoría Penal Pública. Penas sustitutivas de la Ley $N^{\circ} 18.216$ (Santiago, Defensoría Penal Pública, 2014), pp. 12-13. 
de delito consumado de parricidio que hubieren cometido anteriormente ciertos delitos en el contexto intrafamiliar.

De todas formas, la mayoría de los tipos indicados cuentan con penas abstractas elevadas, los cuales aún en ausencia de dicho precepto harían improcedente la aplicación de una pena sustitutiva, no pasando de ser una "concesión nominal" 85 buscando más bien efectos simbólicos amparado en una retórica de carácter punitiva, que modificaciones comportamentales a la realidad delictiva.

Posteriormente el ejecutivo presentó una indicación el 21 de marzo de 2011 que, entre otras materias, eliminó del apartado de exclusión las conductas terroristas y en el caso de los delitos contra la vida lo circunscribió a las formas más lesivas, particularmente parricidio, femicidio y homicidio calificado, como parte de las exclusiones generales.

En el caso de las exclusiones específicas, recondujo la regla relativa a los delitos contra la propiedad desde el robo por sorpresa a exclusivamente los casos de robo con violencia e intimidación que tuvieren condenas previas por delitos de la misma naturaleza.

La citada indicación consideró una exclusión específica respecto de la pena de prestación de servicios en beneficio de la comunidad (en adelante PSBC) -que como se explicará fue incorporada al catálogo para aquellos casos en que no fuere procedente alguna de las otras penas sustitutivasimpidiendo el juzgamiento a PSBC a condenados por crímenes y simples delitos tipificados en la Ley $\mathrm{N}^{\circ} 20.000$ de drogas y sus anteriores legislaciones $^{86}$.

Otra novedad de la reforma consiste en la regulación de una norma especial para el caso que el condenado contare con condenas precedentes cumplidas 5 o 10 años antes de la fecha de la nueva condena, según se

${ }^{85}$ Matus, Jean Pierre, Proyecto de ley que modifica la Ley $N^{\circ} 18.216$ que reemplaza las medidas alternativas al cumplimiento de penas privativas de libertad por "penas sustitutivas", en Revista de Derecho Escuela de Postgrado 5.838-071 (2011), pp. 243248 y 245.

${ }^{86}$ Tratándose de reincidentes, la norma replica la exclusión contenida en el art. 62 de la ley de drogas, respecto de la procedencia de las medidas alternativas, buscando -como explicó la Subsecretaria de Justicia de entonces- solamente "actualizar la terminología utilizada en esta disposición”, descartándose la interpretación expuesta por Aguilar entono a que la regla del art. 62 constituiría una regla "especial"; y estableciéndose como contra excepción los casos en que se hubiere reconocido en la sentencia la atenuante de cooperación eficaz establecida en el art. 22 de la Ley $\mathrm{N}^{\circ} 20.000$, con el objeto de no restringir los instrumentos de negociación con que cuenta el Ministerio Público en estos casos. Aguilar, Cristian, Penas sustitutivas a las penas privativas o restrictivas de la libertad de la Ley $N^{\circ} 18.216$ (Ley 20.603) (Santiago, Editorial Metropolitana, 2013), p. 32 trate de simple delito o crimen, y que en su ausencia impediría acceder a una pena sustitutiva -salvo en el caso de la reclusión parcial y los servicios en beneficio de la comunidad- a infractores reincidentes. Esta norma, inicialmente fue propuesta por el Ejecutivo para los casos en que la condena anterior hubiere sido "dictada" 87 dentro de los 10 años anteriores a la comisión del nuevo ilícito, y sólo para el caso de los simples delitos, regulándose particularmente respecto de cada pena. El fundamento de esta modificación parece haber sido entregar una respuesta punitiva diferenciada entre aquellos infractores que cuentan con carreras criminales activas y persistentes, de aquellos que exhiben más bien patrones ocasionales de delincuencia extendidas a lo largo de su vida ${ }^{88}$, permitiendo en el caso de últimos asimilarlos al régimen de acceso general que favorece a primerizos o infractores reincidentes con limitaciones por delitos de menor gravedad.

Posteriormente, la propuesta fue ampliada a los crímenes ${ }^{89}$ y luego, en el segundo trámite constitucional, con ocasión de una indicación presentada por la entonces Senadora Alvear ${ }^{90}$, se introdujo como norma general en el art. $1^{\circ}$ para el caso de condenas "cumplidas" 91 . En relación al hito de inicio de cumplimiento del cómputo, como precisa Maldonado, si bien existe cierta jurisprudencia que entiende que los respectivos plazos se deben computar a partir de la fecha de "imposición de la condena", con total prescindencia a la exigencia de "cumplimiento" que contiene el texto; lo cierto es que la interpretación más compatible con el tenor literal de la disposición es aquella en que se asocia directamente el cómputo de las fechas al "evento" constitutivo del "cumplimiento" de las sanciones y no al hito que representa su "imposición"

Por otra parte, una de las principales diferencias entre la antigua y la

${ }^{87}$ Historia de la Ley, cit. (n. 79), pp. 24, 26 y 28.

${ }^{88}$ En consonancia con el reconocimiento de la existencia de diferentes tipologías de infractores a la luz de los hallazgos de la Criminología del Desarrollo, como la propuesta inicialmente por MoffiT, Terry, Adolescence-limited and life-coursepersistent antisocial behavior: a developmental taxonomy, Psychol Review, 100, 4, (1993), p. 674.

${ }^{89}$ Historia de la Ley, cit. (n. 79), p. 107

${ }^{90}$ Ibid., pp. 521 y 526

${ }^{91}$ Ibid., pp. 521 y 526

${ }^{92}$ Maldonado, Francisco, Efectos del cumplimiento de la condena precedente en el acceso al régimen de penas sustitutivas previstas en la ley 18.216. Consideraciones sobre el estatuto aplicable a la reiteración delictiva, al margen de la agravante de reincidencia, en Revista de Derecho Universidad Católica del Norte 22 (2015), 2, pp. 243-277 y 273. En el mismo sentido, véase Aguilar, cit. (n. 86), p.31 y 32; Araya, Luis, Régimen de penas sustitutivas. Revisión a la Ley $N^{\circ} 18.216$, Ley $N^{\circ} 20.587$ y Decreto Ley $N^{\circ} 321$ (Santiago, Der Ediciones, 2017), pp. 85-88. 
nueva regulación es que, en caso de revocación de cualquiera de esas penas sustitutivas por incumplimiento o por la comisión de un nuevo delito, se contempla el cumplimiento del saldo de la pena inicial, abonándose a favor del condenado el tiempo de ejecución de dicha pena sustitutiva de forma proporcional, sujeto a las reglas de conversión establecidas en la ley. Vale la pena mencionar que esta norma fue incorporada durante la etapa final de la tramitación legislativa -pues inicialmente y en consistencia con la pretérita regulación sólo se reconocía posibilidad de abono en el caso de la reclusión parcial y luego en el caso de los servicios en beneficio de la comunidad-. Sin embargo, su consagración en términos amplios sirvió de corolario para el efectivo reconocimiento de estas penas como de naturaleza sustitutiva.

Respecto del catálogo de penas propuesto por la indicación del 18 de agosto de 2010, este comprendía: la remisión condicional, la reclusión parcial, la libertad vigilada y la libertad vigilada intensiva y la expulsión de extranjeros. Posteriormente, mediante indicación del 21 de marzo de 2011, se incorporaron los servicios en beneficio de la comunidad. Todas estas penas sustitutivas forman hoy parte de la Ley $\mathrm{N}^{\circ} 20.603$ y serán analizadas a continuación buscando explicar las diferencias con la antigua regulación.

\section{La remisión condicional}

Respecto de la remisión condicional, la reforma mantiene su concepción original, sufriendo modificaciones menores que serán explicadas a propósito de los cambios experimentados por la libertad vigilada. Como se expuso anteriormente, el fundamento penológico de la remisión se basa en la regulación comparada de fórmulas de suspensión y procede en aquellos casos en la intervención del penado aparece innecesaria, lógica que se mantiene bajo la Ley 20.603, salvo por su concepción actual como pena sustitutiva.

\section{La reclusión parcial}

En el caso de reclusión parcial, los cambios contenidos en la reforma son sin duda radicales. Como es evidente, la reclusión parcial es la heredera natural de la reclusión nocturna, la que no sólo cambia de nombre, sino que también cambia su forma de ejecución, aun cuando es la única que preserva su naturaleza jurídica de pena sustitutiva. En efecto, con la reforma propuesta esta pasa de cumplirse exclusivamente de manera nocturna a poder ser decretada en horario diurno, nocturno o de fin de semana por un total de 56 horas semanales, junto a preferirse su ejecución en el domicilio del condenado, pudiendo ser controlada a través del monitoreo telemático.

La regulación también buscó restringir su aplicación en el caso de rein- cidentes, limitando la procedencia de la reclusión parcial hasta dos veces, buscando -como se expuso- recoger uno de los requerimientos planteados por los Diputados integrantes de la Comisión de Constitución ${ }^{93}$. En ese sentido, si bien esta regla mantuvo la posibilidad de su procedencia para reincidentes por penas de corta duración (hasta dos años), limitó su aplicación para el caso de multireincidentes que cumplieren penas cortas.

\section{Libertad vigilada y la libertad vigilada intensiva}

Otros de los cambios profundos de la legislación vinieron de la mano del fortalecimiento de la libertad vigilada. Esto no sólo tuvo como correlato la petición efectuada por los Diputados de la Comisión de Constitución, sino que parece inspirada en la experiencia comparada, tanto en la legislación británica, en el cual su homólogo, la "probation" tiene un lugar central en el marco de las sentencias comunitarias; así como también el caso de Estados Unidos, país de donde emergió por primera vez la figura de los Programas de Supervisión Intensiva (Intensive Supervision Programs), y parecen haber inspirado la versión “intensiva” de esta pena ${ }^{94}$.

De acuerdo al Ministerio de Justicia la "libertad vigilada y la libertad vigilada intensiva, constituyen una de las penas de mayor relevancia para cumplir con los ejes fundamentales del proyecto, toda vez que a diferencia del resto de las penas (remisión condicional, reclusión parcial, expulsión de extranjeros, servicios comunitarios), contienen un proceso de intervención, de mayor o menor intensidad, con el objetivo de cumplir con fines de reinserción social del condenado" ${ }^{\text {95. }}$.

La reforma restringió el marco regulatorio la libertad vigilada a las siguientes hipótesis i) aplicación en casos de condena de penas privativas de la libertad de dos a tres años, ii) y en aquellos casos en que la condena fuere superior a 541 e inferior a dos, tratándose de delitos de microtráfico, conducción en estado de ebriedad causando lesiones graves y el robo por sorpresa. La idea detrás de esta propuesta, fue la de impedir la imposición de la pena más benigna (remisión condicional), que no permitía brindar una intervención de la conducta infractora para dichos casos, optándose por su intervención a través de la libertad vigilada o reclusión parcial ${ }^{96}$, "estimándose que en estos casos resulta aconsejable, por el tipo de delito

${ }^{93}$ Historia de la Ley, cit. (n. 79), p. 64

${ }^{94}$ Sobre el particular, véase Petersilia, Joan - Turner, Susan, Probation and Parole, en Crime and Justice 17 (1993), pp. 281-335.

${ }^{95}$ Véase Ministerio de Justicia, Material para capacitación nueva Ley No18.216 (Santiago, Ministerio de Justicia, 2012), p. 35.

${ }^{96}$ Esta última en virtud de lo dispuesto en el inc. final del art. 4, y también aplicable en libertad vigilada intensiva. 
que se condena, realizar una intervención, de mayor o menor intensidad según el caso en concreto" en sede libertad vigilada o libertad vigilada intensiva a través de la posibilidad de derivarlos a tratamiento especializado. A pesar de ello durante la tramitación legislativa se amplió para estos casos la posibilidad de decretar la reclusión parcial, argumentando razones de equidad que no resultan del todo claros y que a su vez no necesariamente se compatibilizan con las necesidades de intervención de esta población.

Similar solución se entrega en el caso de la libertad vigilada intensiva, la cual se contempló para las siguientes hipótesis i) condenados a penas privativas de tres o más años hasta 5 años, o a ii) condenados a penas superiores a 541 días hasta 3 años, que hubieren cometido ciertos delitos en el contexto intrafamiliar y sexual. De esta forma, tratándose de estos últimos casos, se privilegia el uso de la libertad vigilada intensiva, no siendo procedente la remisión parcial.

Junto con lo anterior, la reforma brinda al juez la posibilidad de imponer, en virtud de lo dispuesto en el art. 17 bis, en la misma sentencia, la obligación de asistir a programas de tratamiento de rehabilitación de carácter ambulatorios, residenciales o una combinación de ambos, cuando el penado padeciere un consumo problemático de drogas o alcohol, confirmado por una evaluación diagnóstica que hubiere evaluado dicha situación. En ese sentido, si bien no habría fundamentos empíricos para argumentar la prevalencia de consumo problemático de drogas o alcohol en población condenada en libertad vigilada simple o intensiva frente al resto de las penas sustitutivas, la opción por privilegiar el tratamiento en esa sede se basa en que una pena más benigna como la remisión condicional, como se explicó, está concebida para abordar delincuencia sin necesidades específicas de intervención. Sin embargo, es evidente que se pueden presentar casos de consumo problemático respecto de sentenciados a otras penas sustitutivas, en los cuales, no corresponderá su tratamiento y, como planteó el profesor López en la discusión parlamentaria, dicho consumo no puede ser óbice para que el juez, en definitiva, los condene a esas sanciones ${ }^{97}$.

Tanto en la libertad vigilada como en la libertad vigilada intensiva, se mantiene la obligación del tribunal de imponerle las siguientes condiciones anteriormente vigentes. Sin embargo, en el caso de la libertad vigilada intensiva, además se estableció la obligación para el juez de imponer ciertas "reglas de conducta" adicionales consistentes en obligaciones de no hacer (prohibición de acudir a determinados lugares, de aproximarse a la víctima o a sus familiares u otras personas) o de hacer ( obligación de

${ }^{97}$ Historia de la Ley, cit. (n. 79), p. 616. mantenerse en el domicilio en un lapso de 8 horas continuas y de cumplir determinados programas formativos, laborales, culturales, de educación vial, sexual o de tratamiento de la violencia); junto con la posibilidad de controlar su cumplimiento a través de monitoreo telemático.

Por su parte, la facultad entregada al juez, de poder imponer la utilización del monitoreo telemático específicamente para el caso de condenados por la comisión de determinados delitos de violencia intrafamiliar y delitos sexuales, obedece, como argumentó el Ministro de Justicia de la época, "a que en estos ámbitos ha tenido mayor eficacia la utilización de este dispositivo en el derecho comparado" "98, agregando que en eso casos sería utilizado el rastreo satelital o GPS como tecnología de supervisión ${ }^{99-100}$.

Otra novedad que vino de la mano de la reforma fue la eliminación o más bien restricción de uso del "informe presentencial”. Si bien en la historia de la ley se da cuenta de la opción del Ejecutivo por su eliminación ${ }^{101}$, no se encuentra una fundamentación clara respecto de la misma. No obstante, esta opción no sólo respondería a un simple "relajamiento de los requisitos" como sugiere Matus ${ }^{102}$, sino que más bien a un reconocimiento de los problemas existentes en el sistema antiguo respecto de dichos informes. Como argumentan Jiménez y Santos, estos no habrían sido readecuados con la entrada en vigencia de reforma procesal penal, reposando en un juicio clínico de peligrosidad ${ }^{103}$, careciendo de la debida objetividad.

A lo anterior se suma que -más allá de lo dispuesto en la ley y en reglamento previos a la reforma en orden a exigirlos-, no resultaba lógico que se solicitara el informe presentencial respecto de unas medidas y no respecto de otras ${ }^{104}$; o que en realidad se exigiera del todo, como fue la opción del ejecutivo. No obstante, como se señaló anteriormente, esta

${ }^{98}$ Ibid., p. 274

${ }^{99}$ Ibid., p. 262.

${ }_{100}$ Sobre los distintos tipos de tecnología que pueden ser utilizadas para el funcionamiento del monitoreo telemático véase Morales, Ana María, Vigilancia en la modernidad tardía: El monitoreo telemático de infractores, en Política Criminal 8 (2013), 16, pp. 408-471.

${ }^{101}$ Historia de la Ley, cit. (n. 79), cit. p. 285.

${ }^{102}$ Matus, cit. (n. 85), p. 244

${ }^{103}$ JiméneZ, María Angélica - SANTOS, Tamara, ¿Qué hacer con las alternativas a la prisión?, en Nova Criminis 1 (2010), pp. 157-240 y 219.

${ }^{104}$ Pudiendo por ejemplo pronunciarse, no sólo respecto de la posibilidad de entregar un tratamiento en libertad, sino que también respecto de lo innecesario del mismo a propósito de la remisión condicional (letra c) y d) del art. 4) o de lo pertinente de la inocuización nocturna, para el caso de reclusión nocturna (art. 8) regulada en la antigua Ley $\mathrm{N}^{\circ} 18.216$. 
corresponde más bien a una restricción de uso que a una eliminación, pues haciendo un guiño a la antigua tradición aún se permite a los intervinientes aportar los antecedentes necesarios para que el Tribunal resuelva acerca de la imposición o no de la libertad vigilada o la libertad vigilada Intensiva y de recurrir a Gendarmería de Chile si el tribunal estima insuficiente lo aportado por los intervinientes.

\section{Servicio en beneficio de la comunidad}

La PSBC, si bien fue considerada en el proyecto original del Ejecutivo buscando que cierta manera "compitiera" con otras alternativas ${ }^{105}$, fue luego eliminada de la discusión en virtud de la indicación del 2009 y finalmente reincorporada mediante una indicación del 2011. En virtud de su regulación, se faculta al tribunal para sustituir la pena privativa de la libertad igual o inferior a 300 días -aun cuando el plazo inicialmente propuesto por el Ejecutivo era de un año de duración-; previo consentimiento del condenado, y haciendo además aplicable la letra c) del art. 8, propio de la reclusión parcial, relativo a la existencia de antecedentes laborales, educacionales, o de otra naturaleza que justificaren la pena. Junto con lo anterior se propuso como fórmula de conversión considerando "cuarenta horas de trabajo comunitario por cada treinta días de privación de libertad", no pudiendo extenderse por más de 8 horas diarias.

Asimismo, la novedad de la regulación propuesta apuntó a regular su procedencia por una sola vez en subsidio del resto de las penas sustitutivas. Esta fórmula "en subsidio" ${ }^{106}$, constituyó uno de los aspectos más controvertidos de su tramitación legislativa. Como argumentaron representantes del Ejecutivo, concebía a los servicios en beneficio de la comunidad como "una alternativa de última chance antes de enviar al condenado a la cárcel y por ello tienen el carácter de pena sustitutiva subsidiaria de las demás"107. Esto dio pie a la discusión en torno al lugar en el marco punitivo que debieran tener este tipo de sanciones, particularmente con relación a la reclusión parcial. Durante la discusión parlamentaria, el profesor López expresó el contrasentido que podría implicar entender los servicios en beneficio de la comunidad como "última chance", toda vez que el sistema establecido para calcular la conversión de penas "arroja, sin lugar a dudas, un efecto

${ }^{105} \mathrm{El}$ proyecto original establecía que podían decretarse - al igual que la reparación del daño, que también se contemplaba como alternativa- en las siguientes hipótesis: a) Si la pena privativa o restrictiva de libertad que imponga la sentencia condenatoria no excede de tres años; y, b) Si el sujeto no ha sido condenado anteriormente por crimen o simple delito.

${ }^{106}$ Historia de la Ley, cit. (n. 79), p. 560

${ }^{107}$ Ibid., p. 564. mayor para la primera de dichas sanciones, pues una persona que ha sido condenada a un año de privación de libertad y cuya pena se sustituye por reclusión parcial, deberá soportar la reclusión domiciliaria por 365 jornadas diurnas o nocturnas, o por 52 fines de semanas consecutivos. En cambio, si ese mismo sentenciado obtiene la conversión de su pena privativa de libertad por otra de trabajos en beneficio de la comunidad, la cumplirá en un plazo de 12 semanas, que es un lapso significativamente menor”. En razón de lo anterior, recomendó que ubicar los servicios en beneficio de la comunidad en rango intermedio entre la reclusión parcial -que es más gravosa- y la remisión condicional, -de menor entidad- ${ }^{108}$.

El argumento expresado por el profesor López es debatible, en la medida que asume la hipótesis máxima que permite la norma atendida la restricción diaria, esto es, que un penado cumpla la pena de servicios en beneficio de la comunidad de manera continua por un lapso de 8 horas diarias, cuestión que no necesariamente ocurrirá en la práctica, especialmente si el penado cuenta con trabajo. En la misma línea, podría argumentarse que la reclusión parcial -nocturna o de fin de semana- resulta menos aflictiva pues permite permanecer a los condenados en sus hogares, mientras que los servicios en beneficio de la comunidad implican un desplazamiento y la realización de un trabajo, lo que puede resultar más gravoso.

Si bien, las percepciones acerca de las sanciones pueden variar dependiendo del tipo de obligación a ejecutar, resulta legítimo preguntarse si quizás la libertad vigilada intensiva con monitoreo telemático debiera haber tomado el lugar de los servicios en beneficio de la comunidad, considerando el perfil reincidente que debiera ingresar a cumplirlas, aun cuando se trate de delitos de menor lesividad ${ }^{109}$. Esto sin duda debiera ser reevaluado a la luz de los hallazgos de las investigaciones nacionales en la materia.

\section{Expulsión de extranjeros}

La última sanción contemplada en el catálogo del art. 1 de la ley es la expulsión de extranjeros, que permite la sustitución de una pena igual o inferior a 5 años por la expulsión del territorio de la república, en el caso que el condenado fuere un extranjero no residente legalmente en el país. La norma también establece una prohibición de reingreso al país del ex-

\footnotetext{
${ }^{108}$ Ibid., pp. 562-563.
}

109 Pudiendo por ejemplo acceder condenados que previamente hubieran cumplido una remisión condicional y una reclusión parcial. 
tranjero expulsado en un plazo de 10 años $^{110}$, por lo que la pena sustitutiva no es la expulsión en sí, sino la de extrañamiento por dicho lapso ${ }^{111-112}$.

$\mathrm{Al}$ respecto, vale la pena mencionar que la regulación de la expulsión tuvo detractores durante la discusión legislativa, tanto del mundo parlamentario como representantes del mundo académico. La más trascendental de dichas críticas dice relación con la renuncia a todo fin de carácter preventivo general, en la medida que la expulsión no permitiría cumplir con la función disuasiva de las penas, al constituir más bien "una real invitación a cometer delito"113. Desde la óptica de la proporcionalidad también resultaba criticable, en la medida que la respuesta pudiera parecer excesivamente gravosa para el caso del extranjero que estuviere buscando asentarse en el país, y extremadamente benigna, en el caso que sólo estuviere en el con el propósito de delinquir, presentándose más bien como una renuncia al ius puniendi en este último caso ${ }^{114}$. Junto con lo anterior, también vale la pena preguntarse respecto de la conveniencia de regular una norma más bien vinculada con el control migratorio, al menos de la forma en que finalmente fue aprobada, con regulaciones propias del derecho penal, apareciendo de cierta forma, ajena al mismo.

\section{CONTRARREFORMAS}

La reforma a la Ley $\mathrm{N}^{\circ} 18.216$, como fue señalado, entró en vigencia gradual a partir de diciembre de 2013, y sin perjuicio de su corta vida, ya ha sufrido modificaciones, las más importantes con la dictación de la Ley $\mathrm{N}^{\circ}$ 20.931 conocida durante su tramitación legislativa como "Agenda Corta Antidelincuencia" -la segunda con tal denominación- ${ }^{115}$ promulgada en

${ }^{110}$ La norma es clara en cuanto a la extensión del plazo citado, por lo que la interpretación ofrecida por Araya en torno a la diferenciación entre simples y delitos, no tendría sustento ni en la historia de la ley ni se deprende del tenor literal de la norma una interpretación distinta. Véase ArAYA, Luis, cit. (n. 92), p.50.

${ }^{111}$ Historia de la Ley, cit. (n. 86), p. 707.

${ }^{112}$ Para un análisis de las discusiones doctrinarias entorno a la naturaleza jurídica de la expulsión, véase SALINERo, Sebastián, La expulsión de extranjeros en el Derecho penal. Una realidad en España, una posibilidad en Chile, en Política Criminal 6 (2011), pp. 106-141.

${ }^{113}$ Salinero, cit. (n. 112), p. 120

${ }^{114}$ Salinero, cit. (n. 112), p. 124.

${ }^{115}$ La primera con tal denominación corresponde a Ley No 20.253, de 14 de marzo de 2008 promulgada bajo el primer gobierno de la Presidenta Bachelet. Para un análisis crítico de su regulación véase ORELLANA, Edison, La primacía de la persecución penal: Reflexiones sobre la prisión preventiva tras las modificaciones introducidas al Código Procesal penal por la ley 20.253 ("Agenda Corta Antidelincuencia"), en Derecho julio de 2016, y las modificaciones realizadas a la Ley de Control de armas en virtud de la Ley $\mathrm{N}^{\circ} 20.813$ de 2015 y la tipificación del delito de tortura en virtud de la Ley $\mathrm{N}^{\circ} 20.968$.

En particular, tratándose de la primera regulación, se agregó un inc. final a su art. 1, estableciendo que, si una misma sentencia impusiere a la persona dos o más penas privativas, estas deberán ser sumadas su duración para efectos de calcular la posibilidad de sustitución. Con esto, como se desprende del debate, se buscó evitar que las penas impuestas a un mismo sujeto en una sentencia se consideraran separadamente para efectos de determinar su procedencia, evitando con ello "un verdadero fraude a la ley" 16.

Por su parte, la citada normativa también introdujo modificaciones a la reclusión parcial impidiendo la procedencia de la reclusión nocturna tratándose de reincidentes que hubieren cometido algunos de los delitos contra la propiedad de especial preocupación de la citada normativa. Asimismo, establece que el Tribunal en caso de decretar la sustitución o la pena mixta, tratándose de determinados delitos, deberá ordenar la toma de muestra biológica para la obtención de la huella genética del condenado de conformidad con lo dispuesto en la Ley $\mathrm{N}^{\circ} 19.970$, so pena de la revocación de la pena sustitutiva o mixta.

Tratándose de las modificaciones a la Ley de control de armas y la ley que tipifica el delito de tortura, básicamente las modificaciones introducidas apuntan a restringir la procedencia de las penas sustitutivas, tratándose de ciertos delitos objeto de su regulación.

Sin entrar en mayor detalle, resulta por un lado necesario mencionar la preocupante continua expansión que ha venido sufriendo el catálogo de improcedencia general con ocasión de modificaciones a tipos penales específicos; y por el otro, cuestionar las modificaciones introducidas por la citada agenda corta. Esto pues los argumentos entregados por el Ejecutivo para su regulación se basaron esencialmente en una apuesta por el control de la criminalidad vía aumento de la severidad de las penas, amparados en un potencial efecto disuasivo que tendría en este caso las restricciones impuestas a reclusión parcial y derechamente un reconocimiento de la incapacitación selectiva como instrumento de política criminal, aun cuando existe controvertida evidencia que apoye sus postulados ${ }^{117}$. Junto con lo anterior, como apunta Guzmán, estas modificaciones constituyen una

y Humanidades 16 (2010), 1, pp. 9-12; MORALES, Ana María, La politica criminal contemporánea: Influencia en Chile del discurso de la ley y el orden, en Política Criminal 7 (2012), 13, pp. 94-146.

${ }^{116}$ Historia de la Ley $N^{\circ} 20.931$ (Valparaíso, Biblioteca del Congreso Nacional Biblioteca del Congreso Nacional, 2016), p. 81

${ }^{117}$ Acerca de la evidencia de la disuasión y de la incapacitación como prevención 
"anomalía o malformación del sistema (...) [que] introducen un defecto estructural por partida doble, dado que no se refieren a grupos generales de infracciones, si no a delitos escogidos nada más que por el específico bien ofendido, y porque descalabran la ensambladura del sistema, general de adaptación, cercenándole o desordenándole el poder modelador de las circunstancias" $" 118$

\section{DisCUSIÓN}

Sobre la base de la exposición histórica expuesta, a continuación se presenta una discusión acerca de los fundamentos que nuestro legislador tuvo presente a la hora ocuparse de las sanciones alternativas a la privación de libertad, sus principales defectos y virtudes, como asimismo otros aspectos relativos al diseño normativo, vinculándolos con el desarrollo comparado en estas materias ${ }^{119}$.

Las alternativas a la privación de libertad se gestan en nuestro país casi de manera paralela a como se fueron desarrollando en los sistemas comparados, esto es, desde comienzos hasta mediados del siglo XX. Las razones para su inclusión obedecen principalmente al carácter negativo de las penas privativas de libertad y a la necesidad de buscar mejores formas de reinserción social de los condenados.

Resulta innegable reconocer que la preocupación acerca de las penas de corta de duración fue uno de los antecedentes inmediatos para el origen y justificación de las alternativas a la privación de libertad, debido al contagio criminógeno, entre otros efectos adversos que implicaba para el sujeto el cumplimiento de una pena intramuros. De esta forma, el legislador chileno acogió la tesis de posibilitar la suspensión de una pena privativa o restrictiva de libertad tratándose de los simples delitos previstos y sancionados en el libro II del Código penal chileno y respecto de personas sin antecedentes penales.

Sin embargo, tras unas décadas de funcionamiento de la remisión condicional, el legislador nacional optó por ampliar la fórmula respecto del marco penal de aplicación, primero a penas de hasta 3 años, y luego con la dictación de la Ley $\mathrm{N}^{\circ} 18.216$ a penas de hasta 5 años, permitiendo

del delito, véase Medina, Juan José, Prevención del delito y seguridad ciudadana (Madrid, Edisofer, 2011).

${ }^{118}$ GuzMán, José Luis, La anomalía de la adaptación de la penalidad en los delitos contra la propiedad según la Ley $N^{\circ} 20.931$, en Defensoría Penal Pública 7 (2017), pp.17-25 y 21.

${ }_{119}$ Para esto se toma como base el trabajo previo de los autores SALINERO Morales - CASTRO, cit. (n. 1). incluso su aplicación respecto de reincidentes, particularmente en el caso de la reclusión nocturna. Cabe mencionar, que dentro de las justificaciones entregadas para la ampliación de las alternativas en el espectro punitivo en la década de los 80 , sirvieron como soporte trabajos empíricos y el aporte de la academia, que aun cuando puedan ser objeto de aprensiones metodológicas, constituyen de los pocos casos en los cuales la ciencia criminológica ha servido de apoyo al Derecho penal en nuestro país.

En ese sentido, el fundamento de la ampliación de las medidas alternativas se basó por un lado en la supuesta mayor efectividad de las alternativas, entendiendo el contexto comunitario como el más apto para la reinserción social; junto con reconocer que el contacto con pares delictivos, que se da especialmente en la cárcel, constituye un factor de riesgo de reincidencia insoslayable. Ambos argumentos consistentes con los observados en la experiencia comparada. Por su parte, dicha ampliación, significó un reconocimiento temprano de que las alternativas no deben ser confinadas exclusivamente como respuesta tratándose de delitos de menor gravedad que conlleven penas cortas privativas de la libertad, sino que constituyen consecuencias idóneas para el abordaje de la delincuencia de mediana gravedad y también para el caso de los reincidentes que hubieren cometidos delitos de menor gravedad.

Sin perjuicio de que la apuesta efectuada por el legislador de fomentar las alternativas fue sin duda acertada, logrando plasmar institutos que ya habían contado con una experiencia exitosa en otros países, como es el caso de las fórmulas de suspensión y la libertad vigilada tomando como ejemplo la probation, vale la pena detenerse en la nomenclatura utilizada y la híbrida naturaleza jurídica bajo las cuales fue concebida la ampliación del catálogo en los años 80. Así el concepto mismo de la "remisión" adoptado tempranamente por la legislación, más cercano a la noción de "perdón” -no obstante, en concreto referirse a las fórmulas de suspensión-, hizo que las alternativas no lograran reconocerse como consecuencias jurídicas que lograran disputar el lugar central de la cárcel, si no que fueran más bien concebidas como una gracia más parecida a la fórmula del indulto bajo el epígrafe de "medidas alternativas". Tampoco abogó a dicho reconocimiento, el que, bajo el mismo rótulo, se incluyera la reclusión nocturna, que constituía claramente una fórmula de sustitución de la pena y que posteriormente en el Código Procesal Penal se reconociera explícitamente la posibilidad, al menos inicialmente, de suspender los simples delitos y las faltas, entrando por tanto a competir con la remisión, aun cuando a poco andar se restringiera exclusivamente a estas últimas.

En ese sentido, al igual que lo observado en la experiencia internacio- 
nal ${ }^{120}$, la regulación de las alternativas en nuestro país ha mostrado carencias que han afectado su desarrollo, particularmente considerando la poca claridad entregada por el legislador en torno a su naturaleza y configuración.

Esta confusión buscó de cierta forma ser superada con la reforma contenida en la Ley $\mathrm{N}^{\circ} 20.603$, la que se preocupó precisamente de dar una nueva configuración a las alternativas bajo el rótulo de "penas sustitutivas", buscando, como se infiere de la discusión legislativa, dar cuenta de su contenido punitivo y de que se trata de sanciones. Lo anterior, aun cuando operen de manera sustitutiva a la pena privativa de la libertad, con las consecuencias que dicha solución acarrea en materia de revocación y de recursos procesales, sin perjuicio que igualmente existan cuestionamientos entorno a la real adecuación de la normativa a dicha fórmula.

Siguiendo con la tendencia a la ampliación de las alternativas, la citada reforma continuó mutando su configuración, como ocurrió con el cambio sufrido por la reclusión nocturna y su paso a reclusión parcial; y ampliando el catálogo a nuevas sanciones como la libertad vigilada intensiva, los servicios en beneficio de la comunidad, la expulsión de extranjeros y regulando con mayor atención la ejecución y control de su cumplimiento. En esto claramente la reforma se inspiró bastante para su configuración en el derecho comparado, especialmente tomando como base las experiencias en torno al uso de tecnologías como el monitoreo telemático y la regulación de las nuevas penas, que ya contaban con bastante desarrollo en países como Estados Unidos, Inglaterra o España ${ }^{121}$.

Sin embargo, hay que hacer presente que su inserción dentro de los marcos penales existentes, esto es, respecto de penas privativas de hasta 5 años (en concreto), hace que el diseño normativo sea bastante rígido e impida la ampliación de las alternativas hacia otras áreas de la criminalidad, especialmente aquella de mediana-mayor gravedad que no correspondan a perfiles de delincuencia prolífica o crónica, en la medida que dicha ampliación del catálogo versó sobre el público objetivo ya existente. En ese sentido, la verdadera innovación de la normativa vino de la mano de la regulación de los servicios en beneficio de la comunidad y de las normas especiales de consideración de las condenas previas, que son las únicas que en definitiva han permitido ampliar el público objetivo, especialmente para el caso de los reincidentes por delitos de baja gravedad o que no contaren

${ }^{120}$ Worrall, Anne - Hoy, Clare, Punishment in the Community ( $2^{a}$ edición, Cullompton, Willan, 2005), pp. 30-31.

${ }^{121}$ Véase Nellis, Mike - BeYens, Kristel - KaminsK, Dan (eds.)., Electronically Monitored Punishment: International and Critical Perspectives (Oxon, Editorial Routledge, 2012), pp. 21-43 y 66-81; TORREs, Nuria, Contenido y fines de la pena de localización permanente, en Revista para el análisis del derecho 1 (2012), pp 1-30. con una carrera criminal estable en el tiempo. Lo anterior constituye una apuesta sin duda positiva como forma de abordar las históricas críticas al uso de las penas cortas de prisión. Resulta evidente el desafío, como lo han emprendido otras legislaciones en base a diversas propuestas doctrinarias, de ampliar el espectro de aplicación de las alternativas a los casos de medianamayor gravedad ${ }^{122}$. Vale la pena recordar que recientes modificaciones en la materia han obrado precisamente en sentido contrario, restringiendo su utilización, especialmente tratándose de los delitos contra la propiedad.

Por otra parte, lo anterior también repercute en la manera que las diversas alternativas deben compartir o competir entre sí, respecto del público objetivo, siendo cuestionables algunas de las soluciones dadas por el legislador. Así, como fue discutido anteriormente, si bien la reclusión parcial aparece como una sanción adecuada al regular el confinamiento domiciliario del condenado, evitando los efectos criminógenos propios del contacto con pares delictivos en los centros de cumplimiento, merece Dudas el que sea la mejor respuesta tratándose de reincidentes, aun cuando hubieren cometido delitos de menor gravedad, si no permite a través de la sanción abordar su conducta infractora reiterada, como podría ocurrir con el despliegue de la libertad vigilada o libertad vigilada intensiva. En ese sentido, es legítimo preguntarse si estas últimas debieran orientarse más bien a un perfil reincidente, que hacerse cargo de la situación de condenados con menores contactos con el sistema de justicia penal, no obstante, el mayor reproche entorno al delito cometido por ellos cometido.

\section{CONCLUSIOnes}

La evolución de las penas alternativas en Chile ha ido de la mano con la regulación en la experiencia comparada y la evidencia criminológica surgida a partir de su implementación y ampliación. Sin embargo, dicha evolución y avance aún descansa de manera importante en la imposición de penas privativas de la libertad, tanto en cuanto a la fórmula utilizada para su regulación -a través de la sustitución de la pena privativa de la libertad-como de los marcos penales contemplados para su utilización -penas privativas de hasta 5 años (en concreto)-. Eso se traduce en la práctica, como revelan recientes investigaciones empíricas, que para "gran parte de los casos (..) la condena importa el cumplimiento efectivo de la misma ${ }^{123}$. Si bien el objetivo del presente trabajo no es el de repasar las investigacio-

${ }^{122}$ Véase en ese sentido a VON HiRSCH, Andrew, Censurar y castigar (Madrid, Editorial Trotta, 1998), pp. 100 ss.

${ }^{123}$ Sustentank, Informe final estudio empirico de penas (Santiago, Ministerio de Justicia y Derechos Humanos, 2016), p. 30. 
nes empíricas sobre la temática, sino efectuar un recorrido histórico de su regulación, vale la pena relevar sus efectos en el sistema sancionatorio y la persistente dependencia en la pena privativa de la libertad como pilar del sistema de juzgamiento penal, más allá de los avances que presentan las regulaciones analizadas.

En ese contexto, resulta evidente la necesidad a futuro, especialmente frente a la inminente discusión de un nuevo Código Penal, de revisar el funcionamiento al alero de la reforma contendida en la Ley $\mathrm{N}^{\circ} 20.603$, y analizar si la regulación resulta suficiente teniendo en mira dos propósitos. Por un lado, para garantizar que las alternativas cuenten con un contenido punitivo propio, independiente de la cárcel, que importen por lo tanto un censura y reproche y les permita disputar legítimamente un lugar dentro de las consecuencias jurídicas; y que, por el otro, estas sean funcionales para el abordaje adecuado de los distintos tipos de criminalidad y a las necesidades de intervención del sujeto, con miras la reducción de la reincidencia delictual. Lo anterior supone una invitación a que como en épocas pasadas, el Derecho Penal se compenetre con la evidencia criminológica disponible sobre su funcionamiento y a diseñar un modelo normativo que satisfaga por un lado las exigencias de proporcionalidad y justicia, y por el otro, constituya herramientas adecuadas para la prevención del delito.

\section{BIBLIOGRAFÍA}

Aguilar, Carlos, Penas sustitutivas a las penas privativas o restrictivas de la libertad de la Ley $N^{\circ}$ 18.216 (Ley 20.603) (Santiago, Editorial Metropolitana, 2013).

Andrews, Donald - Bonta, James - Wortmith, Stephen, The Recent Past and Near Future of Risk andlor Need Assessment, Crime Delinquency 52 (2006), 7.

ARAYA, Luis, Régimen de penas sustitutivas. Revisión a la Ley $N^{\circ} 18.216$, Ley $N^{\circ} 20.587$ y Decreto Ley $N^{\circ} 321$ (Santiago, Der Ediciones, 2017).

BARBERO, Ruperto, ; Condena condicional o suspensión de la ejecución de la pena?, en Anuario de derecho penal y ciencias penales 23 (1970), 1.

Cid, José - LaRrauri, Elena, Penas alternativas a la prisión (Barcelona, Bosch, 1997).

CurY, Enrique, Derecho Penal. Parte General (8a edición, Santiago, Ediciones Universidad Católica de Chile, 2005).

Defensoría Penal Pública. Penas sustitutivas de la Ley No 18.216 (Santiago, Defensoría Penal Pública, 2012).

Etcheberry, Alfredo, Derecho Penal. Parte General (3a edición, Santiago, Editorial Jurídica de Chile, 1997), II.

FONTECILLA, Rafael, La pena (Evolución natural, jurídica y técnica). Los problemas modernos y su influencia en el nuevo derecho penal chileno (Santiago, Imp. Cisneros, 1930).

GARLAND, David, La cultura del control (Madrid, Gédisa, 2001).

Garrido Montt, Mario, Derecho penal. Parte General (Santiago, Editorial Jurídica de Chile, 2007), II
GesCHE, Bernardo, La remisión condicional de la pena (Santiago, Editorial Jurídica de Chile, 1975).

GuZmán, José Luis, La anomalía de la adaptación de la penalidad en los delitos contra la propiedad según la Ley $N^{\circ} 20.931$, en Defensoría Penal Pública 7 (2017).

Hofer, María Eugenia, Medidas alternativas a la reclusión en Chile, Conceptos 4 (2008). JimÉnEZ, María Angélica - SANTOS, Tamara, ¿Qué hacer con las alternativas a la prisión?, en Nova Criminis 1 (2010).

Maldonado, Francisco, Efectos del cumplimiento de la condena precedente en el acceso al régimen de penas sustitutivas previstas en la ley 18.216. Consideraciones sobre el estatuto aplicable a la reiteración delictiva, al margen de la agravante de reincidencia en Revista de Derecho Universidad Católica del Norte 22 (2015), 2.

Matus, Jean Pierre, Proyecto de ley que modifica la Ley $N^{\circ} 18.216$ que reemplaza las medidas alternativas al cumplimiento de penas privativas de libertad por "penas sustitutivas", en Revista de Derecho Escuela de Postgrado, n5.838-071 (2011).

Matus, Jean Pierre, Medidas alternativas a las penas privativas de la libertad en una futura reforma penal chilena, en Boletín Jurídico del Ministerio de Justicia 2 (2003).

Medina, Juan José, Prevención del delito y seguridad ciudadana (Madrid, Edisofer, 2011)

Ministerio de Justicia, Material para capacitación nueva Ley No18.216 (Santiago, Ministerio de Justicia, 2012).

Moffiтt, Terrie, Adolescence-Limited and Life-Course-Persistent Antisocial Behavior: A Developmental Taxonomy, en Psychological Review 100 (1993).

Morales, Ana María, La política criminal contemporánea: Influencia en Chile del discurso de la ley y el orden, en Politica Criminal 7 (2012), 13.

Morales, Ana María, Vigilancia en la modernidad tardía: El monitoreo telemático de infractores, en Politica Criminal 8 (2013), 16.

Morales, Ana María - Muñoz, Nicolás - Welsch, Gherman - Fábrega, Jorge, La reincidencia en el sistema penitenciario chileno (Santiago, Fundación Paz Ciudadana, Universidad Adolfo Ibáñez y Hans Seidel Stiftung, 2012).

Nellis, Mike - BeYEns, Kristal - Kamisk, Dan (eds.), Electronically Monitored Punishment: International and Critical Perspectives (Oxon, Editorial Routledge, 2012).

NovoA, Eduardo, Curso de Derecho Penal Chileno. Parte General (3a edición, Santiago, Editorial Jurídica de Chile, 2010), III

Orellana, Edison, La primacía de la persecución penal: Reflexiones sobre la prisión preventiva tras las modificaciones introducidas al Código Procesal penal por la ley 20.253 ("Agenda Corta Antidelincuencia"), en Derecho y Humanidades 1 (2010), 16

Ortiz, Luis - ArÉvAlo, Javier, Las consecuencias jurídicas del delito (Santiago, Editorial Jurídica de Chile, 2013).

Peña, Silvia, La condena condicional en Chile (Valparaíso, Edeval, 1974).

Petersilia, Joan - Turner, Susan, Probation and Parole, en Crime and Justice 17 (1993).

Politoff, Sergio - Matus, Jean Pierre - Ramírez, María Cecilia, Lecciones de Derecho penal chileno. Parte General (2a Edición, Santiago, Editorial Jurídica de Chile, 2003).

Rojo, Alfredo, La remisión condicional de la ejecución de la pena y las penas cortas de prisión (Santiago, Imp Lers, 1933).

SALINERo, Sebastián, La expulsión de extranjeros en el Derecho penal. Una realidad en España, una posibilidad en Chile, en Politica Criminal 6 (2011). 
Salinero, Sebastián - Morales, Ana María - Castro, Álvaro, Análisis comparado y critico de las alternativas a las penas privativas de libertad. La experiencia española, inglesa y alemana, en Política Criminal 12 (2017), 24.

Solari, Tito - Tudela, Ximena, Remisión condicional de la pena, reclusión nocturna y libertad vigilada. (Comentario sobre el texto legal), en Revista de Derecho de la Pontificia Universidad Católica de Valparaíso 7, (1983).

Sustentank, Informe final. Análisis respecto de las penas aplicadas por los tribunales chilenos con competencia en materia penal y los factores que influyen en su determinación (Santiago, Ministerio de Justicia y Derechos Humanos, 2016).

Torres, Nuria, Contenido y fines de la pena de localización permanente, en Revista para el análisis del derecho 1 (2012).

Von Hirsch, Andrew, Censurar y castigar (Madrid, Editorial Trotta, 1998).

Von LiszT, Franz, Strafrechtliche vorträge und Aufsätze (Berlin, De Gruyter, 1970), I. Worrall, Anne - Hoy, Claire, Punishment in the Community (2 ${ }^{a}$ edición, Cullompton, Willan, 2005). 